\title{
Does Foreign Aid Mitigate the Adverse Effect of Expropriation Risk on Foreign Direct Investment?*
}

\author{
Elizabeth Asiedu ${ }^{\dagger}$ \\ Department of Economics \\ University of Kansas
}

\author{
Yi Jin ${ }^{\ddagger}$ \\ Department of Economics \\ University of Kansas
}

\author{
Boaz Nandwa ${ }^{\S}$ \\ Economic Growth Center \\ Yale University
}

August 2008

\begin{abstract}
We construct a model of FDI, risk and aid, where a country loses access to FDI and aid if the country expropriates FDI. We show that: (i) The threat of expropriation leads to under-investment; (ii) The optimal level of FDI decreases as the risk of expropriation rises; and (iii) Under certain conditions, aid mitigates the adverse effect of expropriation risk on FDI. The empirical analysis employs data for 35 lowincome countries and 28 countries in Sub-Saharan Africa, over the period 1983-2004. We find that risk has a negative effect on FDI, aid mitigates the adverse effect of risk on FDI, and that bilateral and multilateral aid are roughly equivalent at achieving these results. We also provide an estimate of the level of aid that would eliminate expropriation risk, and find that for low-income countries, the amount of aid would need to at least double in order for aid to completely offset the effect of risk.
\end{abstract}

JEL Classification: F34, F35, I20, O19.

Key Words: Expropriation, Foreign Aid, FDI, Risk, Sub-Saharan Africa

Please address all correspondence to:

Yi Jin, Department of Economics, University of Kansas

Phone: (785)864-2848, Fax: (785) 864-5270, Email: yjin@ku.edu

\footnotetext{
${ }^{*}$ We would like to thank David Carr, Dietrich Earnhart, Mohamed El-Hodiri, Kwabena GyimahBrempong, Donald Lien, Ted Juhl, Francis Owusu, Joseph Sicilian and Zhixiong Zeng for helpful comments.

${ }^{\dagger}$ Department of Economics, The University of Kansas, Lawrence, KS 66045. Phone: (785)864-2843, Fax: (785)864-5270, Email: asiedu@ku.edu

${ }^{\ddagger}$ Department of Economics, The University of Kansas, Lawrence, KS 66045. Phone: (785)864-2848, Fax: (785)864-5270, Email: yjin@ku.edu

${ }^{\S}$ Economic Growth Center, Yale University. Email: boaz.nandwa@yale.edu.
} 


\section{Introduction}

When a multinational corporation (MNC) sets up a subsidiary abroad, the MNC faces the risk that its investments may be expropriated by the host country or at least be subject to unpredictable changes in rules and regulations. ${ }^{1}$ One of the reasons for the existence of these types of risk is that there is no supranational entity that enforces contracts across borders. In addition, the sovereignty status of countries limits the extent to which governments can be "punished" for violations of contractual agreements. Although acts of complete expropriation of foreign capital are now rare (Kobrin, 1984; Minor, 1994), changes in laws, regulations and contractual agreements (which we consider as partial expropriation) are quite pervasive, especially in developing countries. ${ }^{2}$ For example, about 60 percent of the firms that participated in the World Business Economic Survey reported that they often had to deal with "unpredictable changes in rules and regulations" which affected their business. ${ }^{3}$ A recent example of a breach of contract between governments and foreign-owned firms is the case of Venezuela. In the early 1990s, Venezuela liberalized its oil industry and signed service agreements with 22 foreign oil companies. Under these contracts, foreign companies managed the oil fields, and Petróleos de Venezuela S.A. (PDVSA), a state-owned firm, purchased the produced oil from the foreign firms at the market rate. However, in February 2006, the government signed a decree that beginning May 2006, PDVSA will have at least 60 percent ownership in the oil production projects managed by foreign oil firms. ${ }^{4}$ The government also retroactively raised corporate income tax on foreign oil companies from 30 percent to 50 percent and increased royalties from

\footnotetext{
${ }^{1}$ See Kobrin (1980), Makhija (1993) and Li (2005) for a detailed discussion about what motivates governments to expropriate FDI.

${ }^{2}$ Kobrin (1984) and Minor (1994) document the number of nationalizations of foreign enterprises in developing countries. Kobrin (1984) covers the period 1960-1979 and Minor (1994) covers 1980-1992. Both studies show that the nationalization of foreign enterprises has declined over time.

${ }^{3}$ The survey was conducted by the World Bank in 1999/2000 and it covered 10,000 firms in 81 countries. See http://info.worldbank.org/governance/wbes/ for more information.

${ }^{4}$ Twenty six foreign oil companies agreed to convert their operations into joint ventures with PDVSA, with PDVSA holding majority shares. Two European firms (Total of France and Eni S.p.A of Italy) refused to operate as a joint venture and hence were expelled. See the April 23, 2006 issue of the Washington Post for more information. Also see Makhija (1993) for a discussion of expropriation incidents in the oil industry by the Venezuelan government in the 1970s and 1980s.
} 
as low as one percent to 33 percent. Interestingly, the government of Bolivia adopted a similar policy in April 2006.

Clearly, country risk that stems from government actions such as a breach of contractual agreements, changes in laws and regulations or the outright nationalization of foreignowned property has an adverse effect on foreign investment. In addition, these types of risk have a more profound effect on foreign direct investment (FDI) than other types of private foreign investment (e.g., portfolio investment). One reason is that FDI is partially irreversible - much of the costs associated with FDI are sunk and therefore cannot be recouped if disinvestment occurs. Indeed, one of the reasons why many poor countries, in particular, countries in Sub-Saharan Africa (SSA) have received very little FDI is that the region is perceived as risky. The lack of FDI in poor countries is troubling because FDI offers many potential advantages to host countries: it is a source of capital, creates employment, boosts wages, enhances the productivity of domestic firms and workers, and promotes economic growth. ${ }^{5}$ Many international development agencies, in particular, the World Bank, consider FDI as one of the effective tools in the global fight against poverty. For example, the key function of the World Bank's Multilateral Investment Guarantees Agency (MIGA) is to facilitate FDI to poor countries by mitigating investor risk. MIGA provides insurance against expropriation, breach of contract, currency transfer restrictions and political risk. ${ }^{6}$ MIGA also provides dispute resolution services to foreign investors and member countries. Furthermore, MIGA offers loan guarantees to foreign investors (which may help reduce risk-capital ratings of projects and thereby lower borrowing costs) and it provides technical assistance for MIGA guaranteed projects. The role of MIGA as a foreign investment risk mitigator is described in these very terms at the agency's website:

MIGA gives private (foreign direct) investors the confidence and comfort they need to make sustainable investments in developing countries. We act as

\footnotetext{
${ }^{5}$ The conclusions from empirical studies on the effect of FDI on host countries economy are far from unanimous. Some find that FDI does not have a signifcant effect, whilst others conclude that the positive effect of FDI will be realized only if certain conditions are met. See Carkovic and Levine (2005) for a review of the literature.

${ }^{6}$ In fiscal year 2007, MIGA issued about $\$ 1.4$ billion in investment guarantees (insurance) in developing countries. About 48 percent of the projects were in low-income countries and about 38 percent were in Africa.
} 
a potent deterrent against government actions that may adversely affect investments. And even if disputes do arise, our leverage with host governments frequently enables us to resolve differences to the mutual satisfaction of all parties. MIGA's relationship with shareholder governments provides additional leverage in protecting investments, by deterring harmful actions by governments. Helping investors overcome their concerns about potential political risks is precisely why MIGA exists.

MIGA also notes at its website that "harmful actions by governments" include the expropriation of property and changes in contractual agreements. Thus, to the extent that the services provided by MIGA can be characterized as foreign aid, the pronouncements by MIGA suggest that multilateral aid, specifically deters expropriation acts by governments, and in general, reduces the risk faced by foreign direct investors. ${ }^{7}$ With regard to bilateral aid, Kimura and Todo (2007) assert that aid serves as a quasi government guarantee for investments in the recipient country that originate from the donor country. As a consequence, aid reduces the level of risk perceived by MNCs from the donor country. Harms and Rauber (2006) also find that both bilateral and multilateral aid improves a country's credit ratings and thereby reduces the level of risk perceived by foreign investors.

This paper examines the link between FDI, aid and expropriation risk. In a seminal paper, Eaton and Gersovitz (1984) showed that the threat of expropriation has a negative effect on FDI. We extend their analysis to determine whether foreign aid can ameliorate this adverse effect. Specifically, we construct a model of FDI, risk and aid, where a country loses access to FDI and aid if the country expropriates FDI. We derive three main results: (i) The threat of expropriation leads to under-investment; (ii) The optimal level of FDI decreases as the risk of expropriation rises; and (iii) Under certain conditions, aid mitigates the adverse effect of expropriation risk on FDI. For the empirical analysis, we consider a panel of two country groups. The first group comprises of 35 low-income countries and the second group consists of 28 countries in $\mathrm{SSA}^{8}$ We consider three measures of aid:

\footnotetext{
${ }^{7}$ The relationship between default risk and aid has already been established in the empirical literature on sovereign lending. For example, Nunnekamp and Picht (1989) conclude that countries that received more subsidized loans were less likely to engage in willful default.

${ }^{8}$ We exclude middle-income countries (MINCs) from our regressions for three reasons. First, most MINCs have little difficulty attracting FDI and therefore our analysis is less pertinent for MINCs. Second,
} 
bilateral, multilateral and aggregate aid, and our analysis covers the period 1983-2004. We run separate regressions for bilateral and multilateral aid because according to the aid literature, the two types of aid are driven by different factors, suggesting that the effect of aid on FDI may be different for bilateral and multilateral aid (Maizels and Nissanke, 1984). We answer three questions: (i) Does expropriation risk have an adverse effect on FDI?; (ii) Can aid ameliorate the adverse effect of risk on FDI?; (iii) Can aid completely neutralize the negative effect of risk on FDI? These questions have important policy implications. For example, if aid can completely overcome the adverse effect of risk, then one may advocate for an increase in aid to developing countries.

As a benchmark, we estimate a reduced form FDI equation. Here, we employ two estimation procedures — the dynamic panel "difference" General Method of Moments (GMM) estimator proposed by Arellano and Bond (1991) and the "system" GMM estimator proposed by Blundell and Bond (1998). We find that risk has a negative and significant effect on FDI, aid mitigates the adverse effect of risk, and that bilateral and multilateral aid are roughly equivalent at achieving these results. We also provide an estimate of the level of aid that would eliminate the negative effect of expropriation risk, and find that for low-income countries, the amount of aid would need to at least double in order for aid to completely offset the effect of risk. These results hold for both sample groups, the three measures of aid as well as the two estimation procedures. We next take into account the possibility that FDI and aid are jointly determined. Here, we extend the theoretical model to consider the case where aid and FDI are jointly determined and estimate by three-stage least squares (3SLS) the structural equations that determine FDI and aid. We find that the results for the 3SLS regressions are qualitatively similar to the GMM estimation results. We also find that the risk-mitigating effect of aid is more

MINCs score low on the measure of expropriation risk, suggesting that expropriation is less of a concern for MINCs. The third reason for excluding MINCs is that the factors that drive FDI to low-income countries are likely to be different from the factors that determine FDI to MINCs (Blonigen and Wang, 2005). In addition, the effect of aid on FDI are likely to be different for the two income groups (Asiedu and Nandwa, 2007). As a consequence, including MINCs in the study would entail carrying out a separate analysis for MINCs, since any analysis based on a pooled sample will be biased. This will make the paper less focused. We therefore focus on countries that are high risk and have trouble attracting FDI. 
pronounced for the 3SLS regressions than the GMM regressions.

This paper is related to two strands of the empirical literature. The first analyzes the effect of country risk on FDI (e.g., Loree and Guisinger, 1995). The consensus is that risk has a negative effect on FDI. The second strand of the literature examines whether aid has a significant effect on FDI. The results are conflicting. ${ }^{9}$ Note that the first strand of studies focus on the direct effect of risk on FDI - i.e., interested in the sign and significance of $\partial F D I / \partial R i s k$, and the second strand of studies focus on the effect of aid on FDI i.e., interested in $\partial F D I / \partial A i d$. We take a different approach in that we are interested in analyzing whether aid can ameliorate the adverse effect of risk on FDI, i.e., whether aid reduces $\partial F D I / \partial R i s k$. Specifically, in answering question (i), we focus on $\partial F D I / \partial R i s k$ and for question (ii) we are interested in the sign and significance of $\frac{\partial}{\partial A i d}(\partial F D I / \partial R i s k)$.

We end this section by providing a rationale for running separate regressions for countries in SSA. Indeed, one may argue that such an analysis is unnecessary because there is an overlap between low-income countries and countries in SSA. However, we focus on SSA for the following five reasons. First, FDI and aid are crucial for poverty reduction in SSA. ${ }^{10}$ Second, aid to SSA has increased substantially since 2002. The average aid per capita increased from about $\$ 20.82$ over the period $1998-2001$ to about $\$ 35.07$ over the period 2002-2005, an increase of more than 68 percent. This trend is expected to continue in the near future. ${ }^{11}$ It is therefore important to analyze the effectiveness of aid to the region. The third reason is that SSA has an "image" problem: the region is perceived as very risky. For example, about 56 percent of the firms that participated in a survey conducted by the United Nations Conference on Trade and Development (UNCTAD) reported that the

\footnotetext{
${ }^{9}$ For example, Chauvet and Mesplé-Somps (2006), Yasin (2005) and Rodrik (1995) analyze whether aid has a significant effect on FDI in SSA. Yasin (2005) finds that bilateral aid has an adverse effect on FDI and multilateral aid does not have a significant effect. Rodrik finds that bilateral aid enhances FDI flows but multilateral aid has a negative effect on FDI. Chauvet and Mesplé-Somps (2006) on the other hand find no relationship between FDI and three measures of aid — bilateral, multilateral and aggregate aid.

${ }^{10}$ This point in noted in the United Nations Millennium Declaration, which states that "... We [the United Nations General Assembly] resolve to take special measures to address the challenges of poverty eradication and sustainable development in Africa, including debt cancellation, improved market access, enhanced Official Development Assistance (i.e., foreign aid) and increased flows of Foreign Direct Investment..." (United Nations (2000), pp. 5)

${ }^{11}$ For example, in 2005 the G8 pledged to raise annual development aid to SSA by $\$ 25$ billion by 2010 — which is more than double the levels in 2004.
} 
actual business environment in SSA was better than the continent's image would suggest (UNCTAD, 2000). ${ }^{12}$ Thus to the extent that risk deters FDI and that FDI is crucial for poverty alleviation, analyzing whether aid can mitigate the adverse effect of risk has important policy implications. Another reason for focusing on SSA is that the determinants of FDI to SSA may be different from the determinants of FDI to other regions (Asiedu, 2002). Also the aid-growth literature suggests that aid may be less effective in countries that are located in the tropics (Dalgaard et. al., 2004). About 92 percent of SSA's territories lie within the tropics (compared with about 3 percent for OECD, 8 percent for North Africa and 60 percent for East Asia), suggesting that the effects of foreign aid in SSA may be different from that in other regions. If the factors that drive FDI to SSA are different from the factors that determine FDI to other regions, or the effect of aid on FDI varies systematically across SSA and non-SSA countries, then estimations that employ a pooled sample of SSA and non-SSA countries will produce misleading results. Finally, there is a widespread notion among policymakers in the region that the conclusions based on studies of countries outside SSA are not applicable to SSA because countries in the African region are so different. Therefore, the findings from studies that are based solely on SSA will have more credibility with policymakers in the region.

The remainder of the paper is as follows. Section 2 outlines the model, Section 3 describes the data and the variables, Section 4 presents the empirical results and Section 5 concludes.

\section{A Simple Model of FDI, Risk and Aid}

The synopsis of the model is as follows. The economy consists of two agents: a poor host country and a foreign firm. The firm engages in FDI by setting up a subsidiary in the poor country and the country receives a fraction of the output from the FDI project. In addition, the poor country receives aid from abroad. Each period, the country may choose to expropriate foreign capital by taking the entire FDI output. If expropriation occurs,

\footnotetext{
${ }^{12}$ This view is also consistent with the empirical results of Haque et. al. (2000) who find that commercial risk-rating agencies often rate African countries as riskier than warranted by the fundamentals.
} 
the country loses access to aid and FDI in future periods. ${ }^{13}$ Thus, the threat of losing FDI and aid deters countries from expropriating FDI.

\section{The Model}

Consider a world with an infinite time horizon and two agents: a foreign firm and a poor host country. The firm operates a project in the host country. It rents capital at a unit cost of $r$. Let $f($.$) denote output per capita, which satisfies the Inada conditions.$ Each period the firm chooses the amount of capital to invest in the FDI project. Let $k_{t}$ denote the amount of capital per capita invested in period $t$. At the end of the period, the output is shared by the firm and the host country: the host country gets $\lambda f\left(k_{t}\right)$, and the remaining output, $(1-\lambda) f\left(k_{t}\right)$, goes to the firm, where $\lambda \in(0,1) .{ }^{14}$ The share, $\lambda$, is chosen by the host country and is known to the firm before the firm makes investment decisions. The host country receives aid from abroad. Let $A$ be the amount of units of output received in the form of aid. Following Asiedu and Villamil (2002), we assume that the income from FDI and aid are consumed in the current period. The main friction is that in each period the host country may choose to expropriate FDI. If expropriation occurs, the entire FDI output accrues to the country and the country retains the aid, however, the country losses access to FDI and aid in future periods. ${ }^{15}$ Note that the environment we consider is stationary. Hence, for a given level of aid, the same equilibrium allocation applies for every period.

For the purpose of exposition, we consider two cases. In Case 1, we consider an environment where there is no risk of expropriation. Here, we derive the unconstrained

\footnotetext{
${ }^{13}$ Our model builds on Asiedu and Villamil (2002) where the authors analyzed how foreign aid and default risk affect sovereign lending. In their model, a country borrows from abroad and also receives aid. If the country defaults on a loan agreement, it receives no more aid or private loans in future. They find that the threat of a default has a negative effect on sovereign lending and that aid reduces the likelihood that a country will default. An important difference between our work and Asiedu and Villamil (2002) is that they focus on default risk and indirect foreign investment (includes sovereign lending and portfolio investment), while we focus on expropriation risk and FDI. As pointed out earlier, the risk of expropriation pertains more to FDI than indirect foreign investment.

${ }^{14}$ We note that $\lambda$ may be interpreted as a tax on output. However, interpreting $\lambda$ as the share of output that accrues to the host country facilitates the presentation of our model.

${ }^{15}$ This trigger strategy punishment is standard in the literature. See Kletzer (1994) and Eaton and Fernandez (1995) for discussions of various penalties. Also, similar to Eaton and Gersovitz (1984), we do not consider the case of partial expropriation.
} 
optimal investment plan. In Case 2, FDI is subject to expropriation risk. We solve for the constrained optimal plan, and analyze how aid and risk affect the optimal level of investment.

\section{Case 1: No Expropriation Risk.}

We start with the foreign firm's problem. For a given share, $\lambda$, the firm chooses $k$ to maximize its profit, which is given by

$$
\pi(k, \lambda)=(1-\lambda) f(k)-r k
$$

Thus, the optimal $k$ satisfies

$$
(1-\lambda) f^{\prime}(k)=r
$$

Clearly the optimal $k$ is a function of $\lambda$, denoted by $k(\lambda)$.

We now turn to the host country's problem. Let $\beta$ be the host country's discount factor and assume that the country has a risk neutral utility. ${ }^{16}$ Then the present discounted utility of income for the country, $Y(k, \lambda)$, is given by:

$$
Y(k, \lambda)=\sum_{t=0}^{\infty} \beta^{t}\left[\lambda_{t} f\left(k_{t}\right)+A_{t}\right]=\frac{1}{1-\beta}[\lambda f(k)+A] .
$$

Taking into account the firm's optimal investment decision, $k(\lambda)$, the host country chooses $\lambda$ to maximize its discounted utility of income, $Y(k(\lambda), \lambda)$. The optimal $\lambda$ satisfies

$$
f(k(\lambda))+\frac{\lambda}{1-\lambda} \frac{\left[f^{\prime}(k(\lambda))\right]^{2}}{f^{\prime \prime}(k(\lambda))}=0 .
$$

Let $\left(k_{u}, \lambda_{u}\right)$ be the unconstrained optimal plan - i.e., when expropriation risk is absent. Then $\left(k_{u}, \lambda_{u}\right)$ is determined by the profit maximizing condition (1) and the utility maximizing condition (3) .

\section{Case 2: Environment with Expropriation Risk.}

The host country can successfully attract FDI only if it can assure the firm that it will not expropriate. A constraint (which we refer to as an expropriation constraint) has to be

\footnotetext{
${ }^{16}$ We focus on risk neutrality to study the effect of "pure expropriation" on investment. Asiedu and Villamil (2002) and Eaton and Gersovitz (1984) make a similar assumption.
} 
satisfied, whereby the discounted payoff from not expropriating is greater than or equal to the discounted payoff from expropriating.

Let $Y^{N E}$ denote the country's discounted income if no expropriation occurs. Then,

$$
Y^{N E}(k(\lambda), \lambda)=\frac{1}{1-\beta}[\lambda f(k(\lambda))+A],
$$

which is the same as $Y(k(\lambda), \lambda)$ in Case 1. If expropriation occurs, the country keeps the total output and aid, and receives no FDI and aid in future periods. Hence, the country's discounted income if expropriation occurs, denoted by $Y^{E}$, is given by:

$$
Y^{E}(k(\lambda))=f(k(\lambda))+A
$$

Clearly, the country will not expropriate if $Y^{N E}(.) \geq Y^{E}($.$) , and thus the expropriation$ constraint can be written as

$$
Y^{N E}(k(\lambda), \lambda) \geq Y^{E}(k(\lambda)) .
$$

Therefore, taking the firm's optimal investment decision, $k(\lambda)$, as given, the host country chooses $\lambda$ to maximize its present discounted utility of income, $Y^{N E}(k(\lambda), \lambda)$, subject to the expropriation constraint, (4). Clearly $\lambda$ is determined by the binding expropriation constraint, $Y^{E}(k(\lambda))=Y^{N E}(k(\lambda), \lambda)$, i.e. ${ }^{17}$

$$
f(k(\lambda))+A=\frac{1}{1-\beta}[\lambda f(k(\lambda))+A] .
$$

Let $\left(k_{c}, \lambda_{c}\right)$ be the constrained optimal plan. Then $\left(k_{c}, \lambda_{c}\right)$ is determined by the profit maximizing condition (1) and the binding expropriation constraint (5).

\section{Measuring Risk}

In order to derive our main results, we need to quantify risk. Recall that in the absence of risk, the optimal investment plan is given by the unconstrained optimal allocation, $\left(k_{u}, \lambda_{u}\right)$. If this plan satisfies the expropriation constraint, then risk is zero. However, if this plan violates the expropriation constraint, then $Y^{E}\left(k_{u}, \lambda_{u}\right)>Y^{N E}\left(k_{u}, \lambda_{u}\right)$, and risk

\footnotetext{
${ }^{17}$ The situation where the expropriation constraint is not binding is not interesting because the solution is the same as in Case 1, i.e., no expropriation risk.
} 
exists. We therefore use the difference between $Y^{E}\left(k_{u}, \lambda_{u}\right)$ and $Y^{N E}\left(k_{u}, \lambda_{u}\right)$ as a measure of risk. Specifically, for a given level of aid, $A$, we define the level of expropriation risk, $R(A)$, in units of income, as

$$
R(A)=Y^{E}\left(k_{u}\right)-Y^{N E}\left(k_{u}, \lambda_{u}\right) .
$$

We now state our main results. The proofs are in Appendix A.

Result (i): The threat of expropriation leads to under-investment: the optimal level of investment is constrained, i.e., $k_{c}<k_{u}$;

Result (ii): The risk of expropriation has an adverse effect on FDI - i.e., $\frac{d k_{c}}{d R}<0$;

Result (iii): Under certain conditions, aid mitigates the adverse effect of expropriation risk on FDI - i.e., $\frac{d}{d A}\left[\frac{d k_{c}}{d R}\right]>0$.

\section{The Data and the Variables}

Our data set consists of two sample groups: 28 countries in SSA and 35 low-income countries (9 non-SSA countries and 26 SSA countries), and the data cover the period 19832004. The years of coverage and the countries included are determined by the availability of data. Specifically, the data on risk are not available for several countries. Table 1 displays the list of countries.

\section{Country Risk}

In order to test the implications of the model, we need data on country risk that measure the likelihood that a country will renege on contractual obligations. To the best of our knowledge such data are not readily available. Thus, to capture expropriation/default risk, we employ data on investor risk from the International Country Risk Guide database, published by The Political Risk Services $(P R S) .{ }^{18}$ The PRS rating is a composite measure derived from the sum of three risk components that affect FDI: (i) The risk of unilateral contract modification or cancellation and, at worst, outright expropriation of foreign owned

\footnotetext{
${ }^{18}$ For more information about the data, see http://www.prsgroup.com/.
} 
assets; (ii) restrictions on profit repatriation; and (iii) payment delays by government. The score of each component ranges from 0-4, where a higher number implies less risk. Thus the PRS risk variable ranges from 0-12. To facilitate the interpretation of the results, we rescaled the data by subtracting the original score from 12 , so that a higher number implies more risk. Table 1 shows the risk ratings for the countries in our sample averaged over the period 1983-2004.

We point out three caveats of the PRS risk variable. First, note that the aspect of the composite risk variable that is most relevant for our analysis is component (i), which measures the risk of expropriation. Unfortunately, the data on expropriation risk alone are not available prior to March 2001. The short series makes panel estimations infeasible. As a consequence we use the composite risk as a proxy for expropriation/default risk. We argue that the PRS measure of risk, although imperfect, is still appropriate for our analysis because it reflects the risk of expropriation and contract repudiation by host country governments. The second caveat is that risk assessments by private rating agencies, such as PRS, do not accurately reflect the risk levels in developing countries. Specifically, the ratings tend to be biased against poor countries or smaller countries. One reason is that private agencies under-invest in collecting and processing information about poor countries (Ferri, 2004). The third drawback of the PRS risk variable is that the ratings are based on the opinions of experts, and hence, are based on perceptions. Perceptions are "noisy" in that they are influenced by the biases of the experts about a particular country. An option is to use an "objective" measure of expropriation risk. ${ }^{19}$ However, to the best of our knowledge, such a measure does not exist. We acknowledge that these limitations make our measure of risk susceptible to measurement errors, which may cause our estimates to be biased. However, we argue that in spite of these caveats, our analysis provides some insight about the effect of risk and aid on FDI flows to poor countries - i.e., the countries in most dire need of FDI.

\section{Foreign Aid}

\footnotetext{
${ }^{19}$ See Asiedu and Freeman (2007) and Kaufmann and Kraay (2007) for a discussion of the advantages and limitations of subjective and objective measures of risk and other governance indicators.
} 
The data on aid are from the OECD's International Development Statistics. Aid may be broadly classified as bilateral or multilateral. Bilateral aid refers to aid from one country (i.e., donor country) to another (i.e., recipient country). Projects or activities executed by multilateral institutions (e.g., the World Bank) or non-governmental organizations on behalf of a donor country are also classified as bilateral aid, since the use of the funds is controlled by the donor country. Multilateral aid refers to projects financed from the regular budgets of multilateral institutions. Thus the classification of aid hinges on "who" controls the funds or project. We define aggregate aid as the sum of bilateral and multilateral aid. Table 1 shows the data for aid averaged over the period 1983-2004. Overall, bilateral aid is much higher than multilateral aid — bilateral aid constitutes about 65 percent of aggregate aid for the countries in our sample.

\section{Other Variables}

As is standard in the literature, the dependent variable is the ratio of net FDI flows to GDP. Our control variables are drawn from the empirical literature on the determinants of FDI. Specifically, we include (exports+imports)/GDP as a measure of trade openness; the number of telephones per 1000 population as a measure of infrastructure availability and the level of development; and GDP growth rate to capture growth opportunities in the host country. Several studies have found that FDI flows are persistent and that lagged FDI are positively related to current FDI (e.g., Karakaplan et. al., 2006). Thus following the literature, we include lagged FDI as an explanatory variable. As is standard in the literature, we average the data over four years to smooth out cyclical fluctuations. The data are from the World Development Indicators (2005) published by the World Bank. The descriptive statistics of the variables are reported in Table 2.

\section{Empirical Analysis}

\subsection{Dynamic Panel Estimations}

As pointed out in Section 3, several studies have found that lagged FDI flows tend to influence current FDI flows. We therefore estimate a linear dynamic panel-data (DPD) 
model to capture the effect of lag FDI flows on current flows. DPD models contain unobserved panel-level effects that are correlated with the lagged dependent variable, rendering standard estimators inconsistent. The General Method of Moments (GMM) estimator proposed by Arellano and Bond (1991) provides consistent estimates for such models. This estimator often referred to as the "difference-GMM" estimator uses lagged values of the first difference of the endogenous variables as instruments. However, as pointed out by Arellano and Bover (1995), lagged levels are often poor instruments for first differences. This problem is mitigated by using the augmented version of the difference-GMM estimator, the "system-GMM" estimator, proposed by Blundell and Bond (1998), which uses additional moment conditions. However, the system-GMM utilizes more instruments and therefore raises the concern that the estimates may be heavily biased (Hahn and Hausman, 2002). For robustness, we report the regressions for the two estimators. We also note that the estimates from this procedure are inconsistent in the presence of autocorrelation. Hence for each regression we test for autocorrelation and also check the validity of the instruments. For all the regressions, our results confirm the absence of autocorrelation and the validity of the instruments.

We estimate the reduced form equation:

$$
\begin{aligned}
F D I_{i t}= & \alpha R i s k_{i t}+\delta A i d_{i t}+\beta R i s k_{i t} \times A i d_{i t}+\rho F D I_{i t-1} \\
& +\Sigma_{j=1}^{J} \gamma_{j} Z_{j i t}+\theta_{i}+\varepsilon_{i t}
\end{aligned}
$$

where index $i$ refers to countries, $t$ to time, $\theta_{i}$ is the country-specific effect, and $Z$ is a vector of control variables discussed in the previous section, and FDI and Aid are FDI/GDP and $A i d / G D P$, respectively. We proceed by answering the three questions posed in the introduction.

Question 1: Does Expropriation Risk have an Adverse Effect on FDI?

To answer this question we estimate equation (7) without the interaction term, Risk $\times$ Aid. Thus we estimate the equation:

$$
F D I_{i t}=\alpha R i s k_{i t}+\delta A i d_{i t}+\rho F D I_{i t-1}+\Sigma_{j=1}^{J} \gamma_{j} Z_{j i t}+\theta_{i}+\varepsilon_{i t} .
$$


Here the parameter of interest is the estimated coefficient of Risk, $\widehat{\alpha}$. Table 3 shows the results for the difference-GMM estimations. Note that $\widehat{\alpha}$ is negative and significant at the one percent level for all the three measures of aid and the two sample groups. For the SSA sample, a one standard deviation $(s d=1.86)$ increase in Risk will decrease $F D I$ by about 0.640 percentage points for aggregate aid, 0.614 percentage points for bilateral aid and about 0.55 percentage points for multilateral aid. We use an example to provide the reader with a better sense of the harmful effect of risk. Consider two countries in SSA that have extremely different risk profiles - Congo Dem. Republic, the riskiest country in the region and Botswana, the country with the lowest risk ratings (see Table 1). Then for the regressions using aggregate aid, a decrease in risk from the level of Congo (Risk $=9.25)$ to the level of Botswana (Risk $=4.231$ ) will increase FDI by about 1.727 percentage points in the short run and by about 2.365 percentage points in the long-run. ${ }^{20}$ Note that the increase in FDI is quite substantial because the average annual growth in FDI for Congo over the period 1983-2004 is about 0.56 percent. As a robustness check we examine the effect of risk on FDI using the system-GMM. To conserve on space, we do not report the full regression results. We find that similar to the difference-GMM, $\widehat{\alpha}$ is negative and significant at the one percent level in all the regressions. Specifically, for the low-income country (LINC) sample, $\widehat{\alpha}$ is equal to $-0.266,-0.282$ and -0.234 , for aggregate aid, bilateral aid and multilateral aid, respectively; and for the SSA sample, $\widehat{\alpha}$ is equal to $-0.328,-0.321$ and -0.287 , for aggregate aid, bilateral aid and multilateral aid, respectively.

We now turn our attention to the other explanatory variables. Table 3 shows that aid has a negative and significant effect on FDI. In explaining this result we draw from Harms and Lutz (2006) who argue that the theoretical impact of aid on FDI is unclear. On the one hand, aid may raise the productivity of private capital by financing public

\footnotetext{
${ }^{20}$ This follows from the fact that the short-run effect of a $\Delta$ change in Risk on FDI is given by $(\widehat{\alpha} \times \Delta)$ and the long-run effect is $(\widehat{\alpha} \times \Delta) /(1-\widehat{\rho})$, where $\widehat{\alpha}$ is the estimated coefficient of Risk and $\widehat{\rho}$ is the estimated coefficient of $F D I_{i t-1}$. Here, $\Delta=(4.231-9.25)$ and from Table $3, \widehat{\alpha}=-0.344$ and $\widehat{\rho}=0.270$. Then $\partial F D I / \partial R i s k=1.727=-0.344 \times(4.231-9.25)$ in the short run and $\partial F D I / \partial R i s k=-2.365=$ $-0.344 \times(4.231-9.25) /(1-0.270)$ in the long run.
} 
infrastructure investments (Dollar and Easterly, 1999). However, aid could also create incentives for rent-seeking activities (Svensson, 2000). Thus, a plausible explanation for our results is that for the countries in our sample, the negative rent-seeking effect of aid dominates the positive infrastructure effect. The estimated coefficient of the lagged FDI is significant, an indication that FDI is persistent. Finally, consistent with many empirical studies on the determinants of FDI, we find that GDP growth, openness to trade and infrastructure availability have a positive and significant effect on FDI.

\section{Question 2: Can Aid Ameliorate the Adverse Effect of Risk on FDI?}

We now test the central hypothesis of the paper, i.e., whether increasing aid leads to a significant reduction in $\partial F D I / \partial R i s k$. Here, we estimate equation (7). Table 4 shows the results for the difference-GMM estimations. Note that $\partial F D I / \partial R i s k=\widehat{\alpha}+$ $\widehat{\beta} \times A i d$, and therefore the parameters of interest are the estimated coefficient of Risk, $\widehat{\alpha}$, and the estimated coefficient of the interaction term, $\widehat{\beta}$. For the two sample groups and for all the measures of aid, $\widehat{\alpha}$ is negative and significant at the one percent level, and $\widehat{\beta}$ is positive and significant at the one percent level, suggesting that aid significantly reduces the adverse effect of risk on FDI. Here again, we use an example to elucidate our results. We consider two countries, Kenya and Gambia, both located in the same region, SSA. Aggregate aid as a share of GDP averaged over the period 19832004 is 7.22 percent for Kenya and 21.9 percent for Gambia (see Table 1). Suppose the risk level in Kenya increases by one sample standard deviation $(s d=1.86$, see Table 2). Then, all else equal, the increase in Risk will decrease FDI by about 0.75 percentage points $[\partial F D I / \partial R i s k=(-0.54+0.019 \times 7.22) \times 1.86=-0.75]$. Now suppose the amount of aid to Kenya was increased to the level of aid to Gambia. Then, a one standard deviation increase in Risk will decrease FDI by only 0.23 percentage points $[\partial F D I / \partial R i s k=(-0.54+0.019 \times 21.9) \times 1.86=-0.23]$, which is about 69 percent less than the expected decrease in FDI under the current level of aid.

We next examine whether our result holds when we employ the system-GMM estimator. To conserve on space we report only the values of $\widehat{\alpha}$ and $\widehat{\beta}$ in Table 5 . The results are 
qualitatively similar to that of the difference-GMM: For the two sample groups and for all the three measures of aid, $\widehat{\alpha}$ is negative and significant at the one percent level, and $\widehat{\beta}$ is positive and significant at the one percent level. Thus, our estimations suggest that the mitigating effect of foreign aid on risk is robust.

We end by pointing out an implication of our results which, at a glance seems puzzling. Note that the marginal effect of aid on FDI is $\partial F D I / \partial A i d=\widehat{\delta}+\widehat{\beta} \times R i s k$. Since $\widehat{\delta}<0$ and $\widehat{\beta}>0$, it follows that higher levels of risk improve the effect of aid on FDI. Indeed, this result is similar to that of Harms and Lutz (2006) who find that aid is more effective in promoting FDI in countries that have a large regulatory burden. Note however, that this result does not imply that higher risk is good for FDI. As discussed above, the overall effect of risk on FDI is negative and significant, suggesting that countries need to lower their risk in order to attract FDI.

Question 3: Can Aid Completely Neutralize the Adverse Effect of Risk on FDI?

Having ascertained that aid mitigates the adverse effect of risk on FDI, a natural question that arises is this: can aid offset the negative effect of risk? For our analysis, we are interested in determining the level of aid that drives $\partial F D I / \partial R i s k$ to zero (i.e., $\widehat{\alpha}+\widehat{\beta} \times A i d=0)$. We proceed by evaluating $\partial F D I / \partial R i s k$ at reasonable values of $A i d$. Table 6 shows the value of $A i d$ at the $25^{\text {th }}$ percentile, $50^{\text {th }}$ percentile and $75^{\text {th }}$ percentile for the two sample groups. Table 7 shows $\partial F D I / \partial R i s k$ evaluated at these three values of Aid.

There are two notable points from Table 7. First, $\partial F D I / \partial R i s k$ decreases substantially as aid increases. For example, the difference-GMM estimations show that increasing aggregate aid from the $25^{t h}$ percentile to the $50^{\text {th }}$ percentile will reduce $\partial F D I / \partial R i s k$ by about 20 percent for the LINC sample, and about 25 percent for the SSA sample. The second notable point is that $\partial F D I / \partial R i s k$ remains negative and significant even when Aid is quite high, as high as the $75^{\text {th }}$ percentile of Aid [for the LINC sample, this is equivalent to about 16 percent of GDP (see Table 6)]. These results suggest that although increasing aid reduces the adverse effect of risk on FDI, aid may not completely neutralize the 
negative effect of risk. To confirm this conjecture, we compare $A i d^{*}$ and $\overline{A i d}$, where $A i d^{*}$ is the critical value of aid, defined as the level of aid at which $\partial F D I / \partial R i s k=0$ and $\overline{A i d}$ is the actual values of aid, averaged over the period 1983-2004. The results shown in Table 8 suggest that completely eliminating risk, will require a substantial increase in aid. For example, for the LINC sample, Aid* is about 32 percent for the difference-GMM estimations and 57 percent for the system-GMM estimations. However, the average aid, $\overline{A i d}$, is a mere 12 percent. Thus Aid will have to increase by about 167 to about 375 percent in order to completely offset the adverse effect of risk on FDI. Indeed, only one country in the sample, Guinea-Bissau, has aid values close to the threshold, Aid*. This result is important because it suggests that although aid may mitigate the adverse effect of risk on FDI, it cannot (realistically), neutralize the negative effect of risk. ${ }^{21}$

\subsection{Joint Determination of FDI and Aid}

The benchmark GMM estimations may be described as a "bare bones" approach to analyzing the role of aid in mitigating the adverse effect of risk on FDI. A major caveat, however, is that the analysis does not include any determinants of aid. Furthermore, it is possible that aid and FDI are determined jointly. On the one hand, a country's ability to attract FDI may influence donors' decision to provide aid. On the other hand, an increase in aid to a country (e.g., aid that results in increased privatizations or aid aimed at boosting a country's physical infrastructure) may affect FDI flows. It is also possible that the factors that cause changes in FDI reflect general conditions in the recipient country that also affect aid allocation.

\footnotetext{
${ }^{21}$ We note that the difference-GMM results are roughly comparable between the low-income and SSA groups, but the results for the two groups are quite different for the system-GMM estimations. This may be partly explained by the fact that the system-GMM estimator utilizes more instruments than the difference-GMM estimator. In addition, the estimates from the system-GMM regressions are sensitive to the sample size, particularly when the sample size is small relative to the number of instruments (Roodman, 2007). When the sample size is small, a small change in the sample size can generate large changes in the estimated coefficients. Note that in such a situation, one should focus on the qualitative differences (sign and statistical significance) rather than the quantitative differences (i.e., the magnitude) of the estimated coefficients. The low-income country sample consists of 35 countries and the SSA sample consists of 28 samples. Thus, a plausible explanation for the difference in the estimated coefficients is the reduction in sample size, from 35 to 28.
} 
In this section, we extend the theoretical model to consider the case where aid and FDI are jointly determined and perform a joint estimation of the structural equations that determine FDI and aid. This approach has at least three advantages. First, the results of the joint estimation serves as a robustness check for the estimates from the reduced form equations reported in Section 4.1. Second, the approach provides explicit information about the factors that influence aid allocation. Such an analysis is important for policy formulation. Finally, although there is a vast empirical literature on the determinants of aid, most of the papers do not estimate a model with micro-foundations. To keep the paper focused, we discuss the empirical results here and show the theoretical model in Appendix B. We also compare the results from the joint estimations with the benchmark GMM estimations.

\subsubsection{Estimation Results}

As expected, donors pursue multiple objectives when providing aid. Aid may be motivated by altruism, for example, reducing poverty in recipient countries. However, aid may also be driven by strategic reasons, such as promoting the ideology or political interest of the donor country. We note that aid to poor countries is likely to be largely motivated by altruism. For example, The Commission for Africa recommended that the G8 should consider "allocating aid to countries where poverty is deepest" (2005, p.99). Our sample comprises largely of low-income countries. Therefore in order to keep the paper focused, we abstract from other determinants of aid and focus on the "recipient-need" factors that affect aid allocation.

We consider three altruistic motivations for providing aid — the desire to help the recipient country to: (i) raise the standard of living of its residents; (ii) meet its debt obligations; and (iii) to restore internal balance. We use $\ln (G D P$ per capita) in constant 2000 dollars as a measure of poverty; ${ }^{22}$ the ratio of public debt to exports as a measure of

\footnotetext{
${ }^{22}$ Some studies have employed alternative measures of poverty, such as infant mortality and life expectancy (e.g., Trumbull and Wall, 1994; Behrman and Sah, 1984). We use income per capita for three reasons. First, the data on infant mortality and life expectancy exhibit very little variation over time within country. This is clearly problematic for a panel data analysis. The second reason is that the World Bank uses income per capita as the eligibility criteria for countries to borrow from the Bank. Finally, we
} 
a countries ability to service its debt, and inflation as a measure of macroeconomic instability. ${ }^{23}$ We also include the square of inflation to test whether inflation has a diminishing effect on aid. Finally, we include the $\ln$ (Population) to test the "small country effect" which stipulates that countries with small populations receive more aid per capita than larger countries. ${ }^{24}$ All the data are from the World Development Indicators CD-ROM, published by the World Bank.

We estimate jointly the dynamic simultaneous equations model with two structural equations by 3SLS:

\section{FDI Equation:}

$$
\begin{aligned}
F D I_{i t}= & \alpha \text { Risk }_{i t}+\delta \text { Aid }_{i t}+\beta \text { Risk }_{i t} \times \text { Aid }_{i t-1}+\rho F D I_{i t-1} \\
& +\gamma_{1} \text { Growth }_{i t}+\gamma_{2} \ln \left(1+\text { Phones }_{i t}+\gamma_{3} \text { Trade }_{i t}+\varepsilon_{i t}\right.
\end{aligned}
$$

Aid Equation: ${ }^{25}$

$$
\begin{aligned}
\text { Aid }_{i t}= & \phi F D I_{i t}+\lambda_{1} \ln (G D P \text { per capita })_{i t}+\lambda_{2} \text { Debt }_{i t} \\
& +\lambda_{3}{\text { In } \text { flation }_{i t}+\lambda_{4}\left(\text { Inflation }_{i t}\right)^{2}+\lambda_{5} \ln \left(\text { Population }_{i t}+v_{i t}\right.}
\end{aligned}
$$

The endogenous variables are $A i d_{i t}$ and $F D I_{i t}$. There are two predetermined variables: the lagged values of $A i d, A i d_{i t-1}$, and the lagged values of $F D I, F D I_{i t-1}$. The remaining variables are exogenous, and $\varepsilon_{i t}$ and $v_{i t}$ are error terms. Note that if $A i d_{i t}$ is correlated with $\varepsilon_{i t}$, then the interaction term, $R i s k_{i t} \times A i d_{i t}$, is also correlated with $\varepsilon_{i t}$. To get around the difficult task of finding appropriate instruments for $R i s k_{i t} \times A i d_{i t}$, we interact $R i s k_{i t}$

argue that income per capita is strongly correlated with most poverty indicators, and therefore income per capita may be interpreted as a broad measure of poverty in recipient countries.

${ }^{23}$ We also experimented with other variables that have been employed in other studies, such as government deficits, terms of trade, openness to trade, political instability and corruption. However, none of the variables displayed a consistent and significant relationship with aid.

${ }^{24}$ There are several explanations for the small country effect. One explanation is that small countries tend to be more open and therefore need more aid to finance their imports. See Dudley and Montmarquette (1976) and Chauvet and Mesplé-Somps (2006) for a detailed discussion about the small country effect and foreign aid allocation.

${ }^{25}$ We considered specifications where we included risk as an explanatory variable, but it was not significant. 
with the lagged value of $A i d$, and include $R i s k_{i t} \times A i d_{i t-1}$ in our regressions. ${ }^{26}$ The idea is that $A i d_{i t-1}$ is less likely to be correlated with $\varepsilon_{i t}$ (Greene, 2006). Thus, this innocuous and simple strategy obviates us from the difficulty of finding appropriate instruments, permits us to address the main objective of the paper, and also keeps the paper focused.

Table 9 presents the regression results. Panel A shows the estimation results for the FDI equation and panel B displays the results for the Aid equation. As shown in Panel A, the results for the 3SLS regressions are qualitatively similar to the results from the GMM estimations. Specifically, the estimated coefficient of Risk, $\widehat{\alpha}$, is negative and significant at least at the 5 percent level for all the three measures of aid and the two sample groups. In addition, the estimated coefficient of the interaction term, $\widehat{\beta}$, is positive and significant at the one percent level in all the regressions, suggesting that aid mitigates the adverse effect of risk on FDI. Overall, the control variables performed quite well. The estimated coefficient of the measure of infrastructure, $\ln (1+$ Phones $)$, is not significant. However, the other explanatory variables are significant at least at the 5 percent level and have the correct signs.

We next examine the effectiveness of aid in reducing $\partial F D I / \partial R i s k$ by evaluating $\partial F D I / \partial R i s k$ at reasonable values of Aid. Table 10 shows the values of Aid at the $10^{\text {th }}$ percentile, $25^{\text {th }}$ percentile, $50^{\text {th }}$ percentile and $75^{\text {th }}$ percentile and Table 11 shows $\partial F D I / \partial R i s k$ evaluated at these four values of Aid. Note that $\partial F D I / \partial R i s k$ decreases as Aid increases. Furthermore, $\partial F D I / \partial R i s k$ loses significance at higher values of Aid. This suggests that aid mitigates the adverse impact of risk on FDI, and that at some point aid neutralizes the effect of risk. The results also suggest that the risk-mitigating effect of aid is more pronounced for the 3SLS regressions than the GMM regressions. For example for the SSA sample, $\partial F D I / \partial R i s k$ is not significant at the $50^{\text {th }}$ percentile of Aid (Table 11), i.e., when Aggregate Aid $=12.055 ;$ Bilateral Aid $=7.121$; and Multilateral

\footnotetext{
${ }^{26}$ Woodridge (2002, p.237) notes that in simultaneous equation models that have interactions among endogenous and exogenous variables, "identification and choice of instruments are too abstract to be useful." He suggests using some squares and cross products of the exogenous variables as additional instruments. However, he also points out that in practice, it is difficult to know which additional functions should be added to the instrument list, and that one has to be cautious about the danger of using too many instruments in their estimations.
} 
$A i d=4.586$ (Table 10). This contrasts with the GMM estimations where $\partial F D I / \partial R i s k$ remains negative and significant at the one percent level at higher values of aid, as high as the $75^{\text {th }}$ percentile (Table 7), i.e., when Aggregate Aid $=15.260 ;$ Bilateral Aid $=9.737$; and Multilateral Aid $=6.248$ (Tables 6). Table 12 shows Aid* and $\overline{A i d}$ and the number of countries whose average $A i d$ exceed the critical value, i.e., $\overline{A i d}>A i d^{*}$. Note that $A i d^{*}$ is quite high. However, the $A i d^{*}$ for the 3SLS is lower than the Aid* for the GMM regressions (compare Tables 8 and 12). Also, for about 5-7 countries (i.e., 15-20 percent of the countries) in the sample, $\overline{A i d}>A i d^{*}$ for the 3SLS estimations. In contrast, for the GMM estimations, there is only one country, Guinea Bissau, for which $\overline{A i d}>A i d^{*}$. This again shows that the risk-mitigating effect of aid on FDI is greater for the 3SLS regressions than the GMM regressions. In summary, the results from the 3SLS and GMM estimation procedures lead to the conclusion that although aid mitigates the adverse effect of risk on FDI, the amount of aid required to completely eliminate this adverse effect is quite high.

We now turn our attention to the Aid equation (Panel B of Table 9). With the exception of inflation, the signs as well as the level of significance of the control variables are consistent across the two sample groups and the three measures of aid. All else equal, poorer countries and countries with a large debt burden will receive more aid. Also, similar to Alesina and Dollar (2000) and Chauvet and Mesplé-Somps (2006), we find that on average, small countries receive more aid per capita. ${ }^{27}$ We also find that the effect of inflation differs by the type of aid. Specifically, inflation is not significant for bilateral aid but is significant at the one percent level for multilateral aid. For the estimations using multilateral aid, the estimated coefficient of inflation is positive and the estimated coefficient of the square of inflation is negative, suggesting that inflation has a positive but diminishing effect on multilateral aid. ${ }^{28}$ Thus, our results suggest that the

\footnotetext{
${ }^{27}$ Indeed, this result is not surprising and can be easily gleaned from our data. For example, for the SSA sample, aid per capita averaged over the period 2000-2004 is about $\$ 72$ for countries with populations less than 3.5 million, and about $\$ 35$ for countries whose populations exceed 3.5 million.

${ }^{28}$ One may interpret the positive association between inflation and multilateral aid as evidence that multilateral aid goes to countries that implement bad policies. Indeed one of the reasons cited for the ineffectiveness of aid to promote growth is that aid goes to countries that have a bad policy environment (Burnside and Dollar, 2000). We take a different view in that inflation may be caused by exogenous factors such as an increase in the price of imports, and not necessarily by policies enacted by government.
} 
objectives of multilateral and bilateral donors converge on some issues (e.g., the need to help poorer countries or heavily indebted countries); but diverges on other issues (e.g., helping countries that are experiencing macroeconomic instability).

\section{Conclusion}

This paper has theoretically and empirically examined the link between FDI, foreign aid and expropriation risk. We find that risk has a negative effect on FDI, aid mitigates the adverse effect of risk on FDI, and that both bilateral and multilateral aid are roughly equivalent at achieving these results. We also find that the amount of aid required to completely eliminate the adverse effect of risk on FDI is implausibly high.

With regard to policy, our results suggest that increasing aid will be beneficial to high risk countries. This recommendation is particularly relevant for countries in Sub-Saharan Africa, since the region is perceived to be very risky. However, we find that realistically, aid cannot completely offset the adverse effect of risk, suggesting that there is a limit to which external assistance, in particular aid, can be helpful. This suggests that countries, even if they receive aid, still need to take measures to reduce the types of risk that deter FDI, such as the lack enforcement of rules and regulations. A note of caution is that one has to be careful about using aid as a tool to mitigate the effect of country risk on foreign investment. The reason is that aid may mask the actual effect of risk and therefore reduce incentives for countries to improve their risk profile. Thus, our results make a case for sequential aid-conditionality, where aid is disbursed only after the recipient country has enacted structural reform to reduce the types of risk that deter FDI.

To the best of our knowledge, this paper is the first to theoretically and empirically analyze the link between FDI, aid and country risk. Indeed, the simple structure of the model provides a useful framework for additional theoretical and empirical analysis. For example, the model may be extended to allow the recipient country to engage in production using a domestic technology. Here, one can analyze and compare the effectiveness of various types of aid in ameliorating the adverse effect of risk on FDI. For example, one may 
compare technical assistance aid with budget-support aid. Technical assistance aid may increase the efficiency of the domestic production technology. ${ }^{29}$ In contrast, aid that comes in the form of budget support augments the country's domestic capital for production and may not increase productivity. The model can also be easily amended to analyze the link between default risk, foreign aid and indirect foreign investment (e.g., sovereign lending or portfolio investment). Clearly, such an analysis will be more relevant for middle-income countries and emerging economies (recall that this paper focuses on FDI and low-income countries). Here, it will be interesting to examine whether aid mitigates the adverse effect of default risk on indirect foreign investment. Another interesting exercise will be to establish a "target level of risk" and also find the level of aid that would drive risk to this non-zero, but "acceptable", target.

\footnotetext{
${ }^{29}$ Technical assistance is intended to finance the transfer of technical and managerial skills for the purpose of building national capacity. See Haque and Khan (1997) for a model where technical assistance is modeled as expatriate skills that contribute to the productivity of local production.
} 


\section{References}

[1] Alesina, A., Dollar, D., 2000. "Who Gives Foreign Aid to Whom and Why?" Journal of Economic Growth 5(1), 33-63.

[2] Arellano, M., Bond, S., 1991. "Some Tests of Specification for Panel Data: Monte Carlo Evidence and an Application to Employment Equations," Review of Economic Studies 58, 277-297.

[3] Arellano, M., Bover, O., 1995. "Another Look at the Instrumental Variable Estimation of Error Component Models," Journal of Econometrics 68(1), 29-51.

[4] Asiedu, E., 2002. "On the Determinants of Foreign Direct Investment to Developing Countries: Is Africa Different?" World Development, 30(1), 107-119.

[5] Asiedu, E., Freeman, J., 2007. "The Effect of Corruption on Investment Growth: Evidence from Firms in Latin America, Sub-Saharan Africa and Transition Countries," University of Kansas Working Paper.

[6] Asiedu, E., Nandwa, B., 2007. "On the Impact of Foreign Aid in Education on Growth: How Relevant is the Heterogeneity of Aid Flows and the Heterogeneity of Aid Recipients?" Review of World Economics 143(4), 631-649.

[7] Asiedu, E., Villamil, A.P., 2002. "Imperfect Enforcement, Foreign Investment, and Foreign Aid," Macroeconomic Dynamics 6, 476-495.

[8] Asiedu, E., Villamil, A.P., 2000. "Discount Factors and Threshold: Foreign Investment when Enforcement is Imperfect," Macroeconomic Dynamics 4, 1-21.

[9] Behrman, J.R., Sah, R.K. 1984. "What Role Does Equity Play in the International Distribution of Development Aid?" in: Syrquin, M., Taylor, L., and Westphal, L., (Eds.), Economic Structure and Performance: Essays in Honor of Hollis B. Chenery, Academic Press, 295-315.

[10] Blonigen, B.A., Wang, M.G., 2005. "Inappropriate Pooling of Wealthy and Poor Countries in Empirical FDI Studies," in: Moran, T., Graham, E., and Blomström, M., (Eds.), Does Foreign Direct Investment Promote Development? Washington, DC: Institute for International Economics, 195-220.

[11] Blundell, R., Bond, S., 1998. "Initial Conditions and Moment Restrictions in Dynamic Panel Data Models," Journal of Econometrics 87, 115-144.

[12] Burnside, C., Dollar, D., 2000. "Aid, Policies and Growth," American Economic Review 90(4), 847-867. 
[13] Carkovic, M., Levine, R., 2005. "Does Foreign Direct Investment Accelerate Economic Growth?" in: Moran, T., Graham, E., and Blomström, M., (Eds.), Does Foreign Direct Investment Promote Development? Washington, DC: Institute for International Economics, 195-220.

[14] Chauvet, L., Mesplé-Somps, S., 2006. "Foreign Direct Investment and Aid in Africa: Can FDI Substitute for Foreign Aid?" Mimeo.

[15] Commission for Africa, 2005. Our Common Interest: Report of the Commission for Africa, London.

[16] Dalgaard, C., Hansen, H., and Tarp, F., 2004. "On the Empirics of Foreign Aid and Growth," The Economic Journal 114(496), 191-216.

[17] Dollar, D., Easterly, W., 1999. "The Search for the Key: Aid, Growth, and Good Policies in Africa," Journal of African Economies 8(4), 546-577.

[18] Dudley, L., Montmarquette, C. 1976. "A Model of the Supply of Bilateral Foreign Aid," American Economic Review 66(1), 132-142.

[19] Eaton, J., Fernandez, R., 1995. "Sovereign debt," in: Grossman, G.M., Rogoff, K., (Eds), Handbook of International Economics, vol. 3, 307-328. Amsterdam: NorthHolland.

[20] Eaton, J., Gersovitz, M., 1984. "A Theory of Expropriation and Deviations from Perfect Capital Mobility," The Economic Journal 94, 16-40.

[21] Ferri, G., 2004. "More Analysts, Better Ratings: Do Rating Agencies invest Enough in less Developed Countries?" Journal of Applied Economics 12(1): 77-98.

[22] Greene, W.H., 2003. Econometric Analysis, Fifth Edition, Prentice Hall.

[23] Hahn, J., Hausman, J., 2002. "Notes of Bias in Estimations for Simultaneous Equation Models," Economic Letters 75, 237-241.

[24] Haque, N.U., Nelson, M., Matheison, D.J., 2000. "Rating Africa: The Economic and Political Content of Risk Indicators," in: Collier, P., Pattillo, C. (Eds.), Investment and Risk in Africa (pp. 33-70). New York: St Martin's Press.

[25] Haque, N., Khan, M.A., 1997. "Institutional Development-Skill Transfer Through a Reversal of Human Capital Flight." IMF Working Paper WP/97/89.

[26] Harms, P., Rauber, M., 2006. "Foreign Aid and Developing Countries Creditworthiness," Mimeo.

[27] Harms, P., Lutz, M., 2006. "Aid, Governance and Private Foreign Investment: Some Puzzling Findings for the 1990s," The Economic Journal 116(513), 773-790. 
[28] Karakaplan, U.M., Neyapti, B., Sayek, S., 2006. "Does Aid Promote Foreign Direct Investment? International Evidence," Mimeo.

[29] Kaufmann, D., Kraay, A., 2007. "Governance Indicators: Where Are We, Where Should We Be Going?" Policy Research Working Paper 4370.

[30] Kimura, H., Todo, Y., 2007. "Is Foreign Aid a Vanguard of FDI? A Gravity-Equation Approach," RIETI Discussion Paper Series 07-E-007.

[31] Kletzer, K.M., 1994. "Sovereign Immunity and International Lending," in: van der Ploeg, F., (Eds.), The Handbook of International Macroeconomics. Oxford: Basil Blackwell.

[32] Kobrin, S.J., 1980. "Foreign Enterprise and Forced Divestment in LDCs," International Organization 34, 65-88.

[33] Kobrin, S.J., 1984. "Expropriation as an Attempt to Control Foreign Firms in LDCs: Trends from 1960 to 1979," International Studies Quarterly 28(3), 329-348.

[34] Li, Q., 2005. "Democracy, Autocracy, and Expropriation of Foreign Direct Investment," Mimeo.

[35] Loree, D., Guisinger, S., 1995. "Policy and non-Policy Determinants of U.S. Foreign Direct Investment," Journal of International Business Studies 26(2), 281-299.

[36] Makhija, M., 1993. "Government Intervention in the Venezuelan Petroleum Industry: An Empirical Investigation of Political Risk," Journal of International Business Studies 24(3), 531-555.

[37] Maizels, A., Nissanke, M.K., 1984. "Motivations for Aid to Developing Countries," World Development 12, 879-900.

[38] Minor, M.S., 1994. "The Demise of Expropriation as an Instrument of LDC Policy, 1980-1992," Journal of International Business Studies 25(1), 177-188.

[39] Nunnenkamp, P., Picht, H., 1989. "Default by Developing Countries in the 1980s: A Cross-Country Analysis of Major Determinants," Welwirtschaftliches Archiv 124, 681-702.

[40] Rodrik, D., 1995. "Why Is There Multilateral Lending," NBER Working Paper 5160.

[41] Roodman, D., 2007. "A short Note on the Theme of too many Instruments," Center for Global Development Working Paper No. 125.

[42] Svensson, J., 2000. "Foreign Aid and Rent-Seeking," Journal of International Economics 51(2), 437-461. 
[43] Trumbull, W., Wall, H., 1994. "Estimating Aid-Allocation Criteria with Panel Data," The Economic Journal 104(425): 876-882.

[44] UNCTAD, 2000. World Investment Report, Cross-border Mergers and Acquisitions and Development (New York and Geneva: United Nations).

[45] United Nations, 2000. "United Nations Millennium Declaration," A.55/L.2, http://www.un.org/millennium/declaration/ares552e.htm.

[46] Woodridge, J.M., 2002. Econometric Analysis of Cross Section and Panel Data, Cambridge, Massachusetts: MIT Press.

[47] Yaari, M.E., 1965. "Uncertain lifetime, Life Insurance, and the Theory of the Consumer," Review of Economic Studies 32, 137-150.

[48] Yasin, M., 2005. "Official Development Assistance and Foreign Direct Investment Flows to Sub-Saharan Africa," African Development Review 17(1), 23-40. 


\section{Appendix A: Proof of Results.}

Result (i): The threat of expropriation leads to under-investment - i.e., the optimal level of investment is constrained, $k_{c}<k_{u}$.

Proof. First note that in both the constrained and unconstrained cases, the firm's profit maximizing condition is satisfied:

$$
\begin{aligned}
\left(1-\lambda_{u}\right) f^{\prime}\left(k_{u}\right) & =r \\
\left(1-\lambda_{c}\right) f^{\prime}\left(k_{c}\right) & =r .
\end{aligned}
$$

Given that $f^{\prime \prime}(k)<0$, it suffices to show that $\lambda_{c}>\lambda_{u}$. Define

$$
g(\lambda) \equiv Y^{N E}(k(\lambda), \lambda)-Y^{E}(k(\lambda))=\left(\frac{\lambda}{1-\beta}-1\right) f(k(\lambda))+\frac{\beta}{1-\beta} A .
$$

The binding expropriation constraint implies that $g\left(\lambda_{u}\right)<g\left(\lambda_{c}\right)=0$. Also,

$$
\frac{d g}{d \lambda}=\frac{1}{1-\beta} f(k)+\left(\frac{\lambda}{1-\beta}-1\right) f^{\prime}(k) \frac{d k}{d \lambda}>0 \text { for } \lambda \leq 1-\beta .
$$

Now, $g\left(\lambda_{c}\right)=0$ implies $\lambda_{c}<1-\beta$. Results follow from the fact that $g($.$) is increasing in$ A. Q.E.D.

Result (ii): The risk of expropriation has an adverse effect on FDI - i.e., $\frac{d k_{c}}{d R}<0$.

Proof. The chain rule implies $\frac{d k_{c}}{d R}=\frac{d k_{c}}{d A} / \frac{d R}{d A}$. Recall that the risk of expropriation can be written as (see (6))

$$
R(A)=\left(1-\frac{\lambda_{u}}{1-\beta}\right) f\left(k_{u}\left(\lambda_{u}\right)\right)-\frac{\beta}{1-\beta} A .
$$

This implies ${ }^{30}$

$$
\frac{d R}{d A}=-\frac{\beta}{1-\beta}<0
$$

To obtain $\frac{d k_{c}}{d A}$, we first need to calculate $\frac{d k_{c}}{d \lambda_{c}}$ and $\frac{d \lambda_{c}}{d A}$. We obtain $\frac{d k_{c}}{d \lambda_{c}}<0$, by differentiating the firm's profit maximizing condition (11) with respect to $\lambda$, and we obtain $\frac{d \lambda_{c}}{d A}<0$, by differentiating the binding constraint $g\left(\lambda_{c}\right)=0$ (equation 12) with respect to $A$. Then $\frac{d k_{c}}{d A}=\left(\frac{d k_{c}}{d \lambda_{c}}\right)\left(\frac{d \lambda_{c}}{d A}\right)>0$. Let

$$
D=\left(1-\beta-\lambda_{c}\right) f^{\prime}\left(k_{c}\right)+r \frac{\left[-f^{\prime \prime}\left(k_{c}\right)\right] f\left(k_{c}\right)}{\left[f^{\prime}\left(k_{c}\right)\right]^{2}}
$$

Then, $D>0$. Finally,

$$
\frac{d k_{c}}{d R}=\frac{d k_{c}}{d A} / \frac{d R}{d A}=\frac{-(1-\beta)}{D}<0 .
$$

\footnotetext{
${ }^{30}$ Note that neither $k_{u}$ nor $\lambda_{u}$ depends on the amount of $\mathrm{Aid}, \mathrm{A}$.
} 
Therefore the expropriation risk has an adverse effect on FDI. Q.E.D.

Result (iii): Under certain conditions, aid mitigates the adverse effect of expropriation risk on FDI - i.e., $\frac{d}{d A}\left[\frac{d k_{c}}{d R}\right]>0$.

Proof. Totally differentiating equation (13) with respect to $A$ yields:

$$
\frac{d}{d A}\left[\frac{d k_{c}}{d R}\right]=\frac{1-\beta}{D^{2}} \frac{d \lambda_{c}}{d A} f^{\prime}\left(k_{c}\right)\left(-\frac{\beta}{1-\lambda_{c}}-1+M\right)
$$

where

$$
M=f\left(k_{c}\right) \frac{\left[-f^{\prime \prime \prime}\left(k_{c}\right)\right] f^{\prime}\left(k_{c}\right)+\left[-f^{\prime \prime}\left(k_{c}\right)\right]^{2}}{f^{\prime \prime}\left(k_{c}\right)\left[f^{\prime}\left(k_{c}\right)\right]^{2}} .
$$

If $f^{\prime \prime \prime}\left(k_{c}\right) \leq 0$, then $M$ is negative and $\frac{d}{d A}\left[\frac{d k_{c}}{d R}\right]>0$. If $f^{\prime \prime \prime}\left(k_{c}\right)>0$, we cannot determine the sign of $M$ without a specific functional form of the production function. For simplicity, we assume that $f(k)=k^{\theta}, 0<\theta<1$. Under this specification, $M$ is equal to 1 . Thus,

$$
\frac{d}{d A}\left[\frac{d k_{c}}{d R}\right]=\frac{1-\beta}{D^{2}} \frac{d \lambda_{c}}{d A} f^{\prime}\left(k_{c}\right)\left(-\frac{\beta}{1-\lambda_{c}}\right)>0 .
$$

Since $d k_{c} / d R<0, \frac{d}{d A}\left[\frac{d k_{c}}{d R}\right]>0$ implies that an increase in $A$ reduces the magnitude of $\frac{d k_{c}}{d R}$ and therefore aid mitigates the adverse effect of risk on FDI.

\section{Appendix B: Joint Determination of FDI and Aid.}

The maximization problem of the firm and poor country remain the same as in Section 2. The poor country takes the amount of aid, $A$, as given and chooses the output share, $\lambda$, optimally and the firm takes $\lambda$ as given and chooses the level of FDI, $k$, optimally. Instead of $A$ being exogenous, we assume that the donor is motivated by altruism and cares about the amount of FDI and the amount of aid that flows to the poor country. Let $U$ be the utility function of the donor and assume $U_{1}, U_{2}>0, U_{12}=U_{21}>0$, and $U_{11}, U_{22}<0$, where $U_{1}$ and $U_{2}$ are the first order derivative of $U$ with respect to $k$ and $A$, respectively, and $U_{i j}$ is the $i j$-th second order derivative. Let $q(A)$ be the cost of disbursing aid and assume that $q^{\prime}>0$ and $q^{\prime \prime} \geq 0$. Finally, let $\gamma \in(0,1)$ be the discount factor of the donor. Then the donor takes $k$ as given and chooses $A$ to maximize its utility, which is given by:

$$
\max \frac{1}{1-\gamma}\{U[f(k), A]-q(A)\} .
$$

The optimal $A$ satisfies the first order condition:

$$
U_{2}[f(k), A]=q^{\prime}(A)
$$

Clearly the optimal aid depends on $k$, denoted by $A(k)$. Combining the optimal FDI, $k(\lambda(A))$, with the optimal aid, $A(k)$, allows for a joint determination of FDI and aid. Let 
$A_{u}$ be the unconstrained optimal aid and $A_{c}$ be the constrained optimal aid. Then $A_{u}$ and $A_{c}$ satisfy (14) when $k=k_{u}$ and $k=k_{c}$, respectively. We now derive the three results. Note that the firm's and the poor country's problems are unchanged and therefore Result (i) holds. Also recall that risk is defined as (see (6)):

$$
R=\left(1-\frac{\lambda_{u}}{1-\beta}\right) f\left(k_{u}\right)-\frac{\beta}{1-\beta} A_{u}
$$

For Result (ii) and (iii), we need to show that $\frac{d k_{c}}{d R}<0$ and $\frac{d\left(d k_{c} / d R\right)}{d A_{c}}>0$, respectively. Since $A$ is endogenous, we achieve this by examining how changes in the discount factor, $\beta$, which is an exogenous parameter, affects $R, k_{c}$ and $A_{c}$. Here, we draw from Asiedu and Villamil (2000) and Yaari (1965), who model the discount factor a decreasing function of a country-specific risk factor that reflects the probability that a country will default on a loan agreement. ${ }^{31}$ Specifically, we use the formulae:

$$
\frac{d k_{c}}{d R}=\frac{d k_{c} / d \beta}{d R / d \beta} \text { and } \frac{d\left(d k_{c} / d R\right)}{d A_{c}}=\frac{d\left(d k_{c} / d R\right) / d \beta}{d A_{c} / d \beta} .
$$

Our calculations show that it is difficult to determine the sign of $\frac{d k_{c}}{d R}$ without assuming a functional form for $U(),. q($.$) and f($.$) . Thus, for simplicity we assume U=[f(k)]^{\alpha} A^{1-\alpha}$, $q(A)$ is linear, and $f(k)=k^{\theta}$, with $0<\alpha<1$ and $0<\theta<1$. Then it is easy to show Result (ii):

$$
\frac{d k_{c}}{d R}=\frac{d k_{c} / d \beta}{d R / d \beta}=-\frac{\theta\left[f\left(k_{c}\right)+A_{c}\right](1-\beta)^{2}}{r\left[\lambda_{u} f\left(k_{u}\right)+A_{u}\right](1-\theta)}<0 .
$$

Also note that

$$
\begin{aligned}
\frac{d\left(d k_{c} / d R\right)}{d \beta} & =-\frac{\theta\left[f\left(k_{c}\right)+A_{c}\right](1-\beta)}{r\left[\lambda_{u} f\left(k_{u}\right)+A_{u}\right](1-\theta)}\left(\frac{\theta}{1-\theta} \frac{1-\beta}{\beta}-2\right), \\
\frac{d A_{c}}{d \beta} & =\frac{A_{c}}{1-\lambda_{c}} \frac{\left[f^{\prime}\left(k_{c}\right)\right]^{2}\left[f\left(k_{c}\right)+A_{c}\right]}{\left[f\left(k_{c}\right)\right]^{2}\left[-f^{\prime \prime}\left(k_{c}\right)\right]}>0,
\end{aligned}
$$

Thus when $\beta>\frac{\theta}{2-\theta}, \frac{d\left(d k_{c} / d R\right)}{d \beta}>0$ and $\frac{d\left(d k_{c} / d R\right)}{d A_{c}}=\frac{d\left(d k_{c} / d R\right) / d \beta}{d A_{c} / d \beta}>0$ and therefore Result (iii) follows.

\footnotetext{
${ }^{31}$ Specifically, $\beta$ is defined as $\beta=\phi \rho$, where $\phi$ denotes an idiosyncratic factor that reflects the "patience" of decision makers in the poor country, and $\rho=1 / r$ is the common pure discount factor. As $\phi$ falls, the "country specific" $\beta$ falls, indicating that the country becomes more myopic, and thereby increases the likelihood of a default.
} 
Table 1

List of Countries

\begin{tabular}{|c|c|c|c|c|}
\hline $\begin{array}{l}\text { Countries in Sub- } \\
\text { Saharan African }\end{array}$ & Risk & Aggregate Aid/GDP (\%) & Bilateral Aid/GDP (\%) & Multilateral Aid/GDP (\%) \\
\hline Botswana* & 4.231 & 3.663 & 2.788 & 0.874 \\
\hline Burkina Faso & 6.809 & 13.873 & 8.767 & 5.106 \\
\hline Cameroon & 6.720 & 4.601 & 3.342 & 1.259 \\
\hline Congo, Dem. Rep. & 9.250 & 14.753 & 11.490 & 3.263 \\
\hline Congo, Rep. & 7.668 & 5.573 & 4.627 & 0.946 \\
\hline Cote d'Ivoire & 6.753 & 5.115 & 3.523 & 1.592 \\
\hline Ethiopia & 8.486 & 12.988 & 6.845 & 6.144 \\
\hline Gabon & 6.528 & 1.715 & 1.452 & 0.263 \\
\hline Gambia, The & 6.165 & 21.864 & 10.677 & 11.187 \\
\hline Ghana & 6.731 & 9.197 & 4.826 & 4.372 \\
\hline Guinea & 6.839 & 9.403 & 4.705 & 4.698 \\
\hline Guinea-Bissau & 7.123 & 48.769 & 29.334 & 19.435 \\
\hline Kenya & 6.267 & 7.219 & 4.791 & 2.428 \\
\hline Madagascar & 6.976 & 10.479 & 5.946 & 4.533 \\
\hline Malawi & 6.210 & 22.469 & 11.239 & 11.230 \\
\hline Mali & 7.479 & 17.795 & 11.226 & 6.569 \\
\hline Mozambique & 7.550 & 31.281 & 22.233 & 9.048 \\
\hline Niger & 7.655 & 15.091 & 9.426 & 5.665 \\
\hline Nigeria & 7.677 & 0.574 & 0.313 & 0.261 \\
\hline Senegal & 6.208 & 11.639 & 8.090 & 3.549 \\
\hline Sierra Leone & 9.182 & 20.701 & 11.685 & 9.016 \\
\hline South Africa* & 4.257 & 0.360 & 0.277 & 0.083 \\
\hline Sudan & 8.363 & 4.298 & 2.939 & 1.360 \\
\hline Tanzania & 6.174 & 16.780 & 11.201 & 5.579 \\
\hline Togo & 6.849 & 9.945 & 6.092 & 3.853 \\
\hline Uganda & 6.576 & 11.760 & 6.060 & 5.700 \\
\hline Zambia & 6.873 & 18.825 & 11.592 & 7.233 \\
\hline Zimbabwe & 8.438 & 3.910 & 3.056 & 0.853 \\
\hline \multicolumn{5}{|l|}{$\begin{array}{l}\text { Countries outside } \\
\text { Sub-Saharan } \\
\text { African }\end{array}$} \\
\hline Bangladesh & 7.826 & 4.479 & 2.471 & 2.008 \\
\hline Haiti & 9.800 & 8.734 & 6.263 & 2.471 \\
\hline India & 6.611 & 0.548 & 0.272 & 0.276 \\
\hline Mongolia & 6.163 & 20.670 & 13.769 & 6.901 \\
\hline Nicaragua & 8.302 & 17.035 & 12.274 & 4.761 \\
\hline Pakistan & 7.939 & 2.256 & 1.072 & 1.184 \\
\hline Papua New Guinea & 7.165 & 9.241 & 8.070 & 1.171 \\
\hline Vietnam & 7.098 & 3.375 & 2.186 & 1.189 \\
\hline Yemen, Rep. & 5.500 & 4.406 & 2.547 & 1.859 \\
\hline
\end{tabular}

Notes: * refers to countries in Sub-Saharan Africa that are not low-income. The data are averages over the period 1983-2004. Risk ranges from 0-12, a higher number implies more risk. Aggregate aid is the sum of bilateral and multilateral aid. 
Table 2

Descriptive Statistics

\begin{tabular}{|l|c|c|c|c|}
\hline \multirow{2}{*}{ Variable } & \multicolumn{2}{|c|}{ Low-Income } & \multicolumn{2}{c|}{ Sub-Saharan Africa } \\
\cline { 2 - 5 } & Mean & Std. Dev. & Mean & Std. Dev. \\
\hline FDI/GDP (\%) & 1.536 & 2.254 & 1.432 & 2.179 \\
\hline Risk & 7.414 & 1.763 & 7.049 & 1.856 \\
\hline ln (1+Phones per 1000 Population) & 1.920 & 0.789 & 1.890 & 0.874 \\
\hline GDP Growth (\%) & 2.832 & 3.389 & 2.750 & 3.436 \\
\hline Trade/GDP (\%) & 59.168 & 29.348 & 59.938 & 25.652 \\
\hline Inflation (\%) & 16.651 & 19.162 & 17.891 & 20.312 \\
\hline ln (GDP per capita) & 5.784 & 0.573 & 5.640 & 0.559 \\
\hline Public and publicly guaranteed debt service (\% of exports) & 16.026 & 8.751 & 16.865 & 8.799 \\
\hline ln (Population) & 9.447 & 1.549 & 9.277 & 1.051 \\
\hline Aggregate Aid/GDP (\%) & 12.340 & 11.356 & 12.602 & 12.003 \\
\hline Bilateral Aid/GDP (\%) & 7.759 & 7.509 & 7.773 & 7.798 \\
\hline Multilateral Aid/GDP (\%) & 4.581 & 4.487 & 4.829 & 4.802 \\
\hline
\end{tabular}

Table 3

The (Direct) Effect of Risk on FDI: Difference GMM Regressions

\begin{tabular}{|c|c|c|c|c|c|c|}
\hline \multirow[t]{2}{*}{ Variables } & \multicolumn{3}{|c|}{ Low-Income } & \multicolumn{3}{|c|}{ Sub-Saharan Africa } \\
\hline & $\begin{array}{c}\text { (1) } \\
\text { Aggregate } \\
\text { Aid }\end{array}$ & $\begin{array}{c}(2) \\
\text { Bilateral } \\
\text { Aid } \\
\end{array}$ & $\begin{array}{c}\text { (3) } \\
\text { Multilateral } \\
\text { Aid }\end{array}$ & $\begin{array}{l}(4) \\
\text { Aggregate } \\
\text { Aid } \\
\end{array}$ & $\begin{array}{c}(5) \\
\text { Bilateral } \\
\text { Aid } \\
\end{array}$ & $\begin{array}{c}\text { (6) } \\
\text { Multilateral } \\
\text { Aid }\end{array}$ \\
\hline Risk $(\hat{\alpha})$ & $\begin{array}{c}-0.184^{* * *} \\
(0.000)\end{array}$ & $\begin{array}{c}-0.206 * * * \\
(0.000)\end{array}$ & $\begin{array}{c}-0.144^{* * *} \\
(0.000)\end{array}$ & $\begin{array}{c}-0.344 * * * \\
(0.000)\end{array}$ & $\begin{array}{c}-0.330 * * * \\
(0.000)\end{array}$ & $\begin{array}{c}-0.296 * * * \\
(0.000)\end{array}$ \\
\hline Aid $(\widehat{\delta})$ & $\begin{array}{c}-0.031^{* * *} \\
(0.000)\end{array}$ & $\begin{array}{c}-0.033^{* * *} \\
(0.000)\end{array}$ & $\begin{array}{c}-0.056^{* * *} \\
(0.000)\end{array}$ & $\begin{array}{c}-0.021^{* * *} \\
(0.000)\end{array}$ & $\begin{array}{l}-0.017^{*} \\
(0.095)\end{array}$ & $\begin{array}{c}-0.056^{* * *} \\
(0.000)\end{array}$ \\
\hline Lagged FDI/GDP & $\begin{array}{c}0.270 * * * \\
(0.000)\end{array}$ & $\begin{array}{c}0.268^{* * *} \\
(0.000)\end{array}$ & $\begin{array}{c}0.265^{* * * *} \\
(0.000)\end{array}$ & $\begin{array}{c}0.321^{* * *} \\
(0.000)\end{array}$ & $\begin{array}{c}0.314^{* * *} \\
(0.000)\end{array}$ & $\begin{array}{c}0.317^{* * * *} \\
(0.000)\end{array}$ \\
\hline $\ln (1+$ Phones) & $\begin{array}{c}1.127 * * * \\
(0.000)\end{array}$ & $\begin{array}{c}1.146^{* * *} \\
(0.000)\end{array}$ & $\begin{array}{c}1.144^{* * *} \\
(0.000)\end{array}$ & $\begin{array}{c}0.854 * * * \\
(0.000)\end{array}$ & $\begin{array}{c}0.852 * * * \\
(0.000)\end{array}$ & $\begin{array}{c}0.957 * * * \\
(0.000)\end{array}$ \\
\hline GDP Growth & $\begin{array}{c}0.076^{* * * *} \\
(0.000)\end{array}$ & $\begin{array}{c}0.081^{* * * *} \\
(0.000)\end{array}$ & $\begin{array}{c}0.065^{* * * *} \\
(0.000)\end{array}$ & $\begin{array}{c}0.016^{* *} \\
(0.034) \\
\end{array}$ & $\begin{array}{c}0.021 * * * \\
(0.000)\end{array}$ & $\begin{array}{l}0.018^{* *} \\
(0.041)\end{array}$ \\
\hline Trade/GDP & $\begin{array}{c}0.016^{* * *} \\
(0.000)\end{array}$ & $\begin{array}{c}0.016 * * * \\
(0.000)\end{array}$ & $\begin{array}{c}0.016^{* * *} \\
(0.000)\end{array}$ & $\begin{array}{c}0.008 * * * \\
(0.000)\end{array}$ & $\begin{array}{c}0.008 * * * \\
(0.000)\end{array}$ & $\begin{array}{c}0.007 * * * \\
(0.000)\end{array}$ \\
\hline Constant & $\begin{array}{c}-0.403^{* *} \\
(0.015)\end{array}$ & $\begin{array}{l}-0.354^{*} \\
(0.067)\end{array}$ & $\begin{array}{c}-0.805^{* * *} \\
(0.000)\end{array}$ & $\begin{array}{c}1.715^{* * * *} \\
(0.000)\end{array}$ & $\begin{array}{c}1.593 * * * \\
(0.000)\end{array}$ & $\begin{array}{c}1.343^{* * *} \\
(0.000)\end{array}$ \\
\hline $\begin{array}{l}\text { Sargan Test (p- } \\
\text { value) }\end{array}$ & 0.5525 & 0.4418 & 0.7661 & 0.4685 & 0.6264 & 0.6117 \\
\hline $\begin{array}{l}\text { 2nd Order } \\
\text { Autocorrelation } \\
\text { (P-value) }\end{array}$ & 0.8205 & 0.7755 & 0.8117 & 0.1665 & 0.1716 & 0.1837 \\
\hline $\begin{array}{l}\text { Number of } \\
\text { Observations }\end{array}$ & 154 & 154 & 157 & 125 & 125 & 128 \\
\hline $\begin{array}{l}\text { Number of } \\
\text { Countries }\end{array}$ & 35 & 35 & 35 & 28 & 28 & 28 \\
\hline
\end{tabular}


Table 4

Effect of Risk and Aid on FDI: Difference GMM Estimations

\begin{tabular}{|c|c|c|c|c|c|c|}
\hline \multirow[b]{2}{*}{ Variables } & \multicolumn{3}{|c|}{ Low-Income } & \multicolumn{3}{|c|}{ Sub-Saharan Africa } \\
\hline & $\begin{array}{l}\text { (1) } \\
\text { Aggregate } \\
\text { Aid }\end{array}$ & $\begin{array}{c}(2) \\
\text { Bilateral } \\
\text { Aid }\end{array}$ & $\begin{array}{c}\text { (3) } \\
\text { Multilateral } \\
\text { Aid }\end{array}$ & $\begin{array}{l}\text { (4) } \\
\text { Aggregate } \\
\text { Aid }\end{array}$ & $\begin{array}{c}(5) \\
\text { Bilateral } \\
\text { Aid }\end{array}$ & $\begin{array}{c}(6) \\
\text { Multilateral } \\
\text { Aid }\end{array}$ \\
\hline $\operatorname{Risk}(\hat{\alpha})$ & $\begin{array}{c}-0.322 * * * \\
(0.000)\end{array}$ & $\begin{array}{c}-0.330 * * * \\
(0.000)\end{array}$ & $\begin{array}{c}-0.225^{* * *} \\
(0.000)\end{array}$ & $\begin{array}{c}-0.540 * * * \\
(0.000)\end{array}$ & $\begin{array}{c}-0.518^{* * *} \\
(0.000)\end{array}$ & $\begin{array}{c}-0.452 * * * \\
(0.000)\end{array}$ \\
\hline $\operatorname{Aid}(\widehat{\delta})$ & $\begin{array}{c}-0.107 * * * \\
(0.000)\end{array}$ & $\begin{array}{c}-0.141 * * * \\
(0.000)\end{array}$ & $\begin{array}{c}-0.207 * * * \\
(0.000)\end{array}$ & $\begin{array}{c}-0.160 * * * \\
(0.000)\end{array}$ & $\begin{array}{c}-0.254^{* * *} \\
(0.000)\end{array}$ & $\begin{array}{c}-0.325 * * * \\
(0.000)\end{array}$ \\
\hline Risk*Aid $(\hat{\beta})$ & $\begin{array}{l}0.010^{* * *} \\
(0.000)\end{array}$ & $\begin{array}{l}0.015 * * * \\
(0.000)\end{array}$ & $\begin{array}{l}0.019 * * * \\
(0.000)\end{array}$ & $\begin{array}{l}0.019 * * * \\
(0.000)\end{array}$ & $\begin{array}{c}0.030^{* * *} \\
(0.000)\end{array}$ & $\begin{array}{c}0.034 * * * \\
(0.000)\end{array}$ \\
\hline \multicolumn{7}{|l|}{ Control Variables } \\
\hline Lagged FDI/GDP & $\begin{array}{l}0.291 * * * \\
(0.000)\end{array}$ & $\begin{array}{l}0.311^{* * *} \\
(0.000)\end{array}$ & $\begin{array}{l}0.261 * * * \\
(0.000)\end{array}$ & $\begin{array}{c}0.298 * * * \\
(0.000)\end{array}$ & $\begin{array}{l}0.301 * * * \\
(0.000)\end{array}$ & $\begin{array}{l}0.324^{* * *} \\
(0.000)\end{array}$ \\
\hline $\ln (1+$ Phones $)$ & $\begin{array}{l}1.021 * * * \\
(0.000)\end{array}$ & $\begin{array}{c}1.001 * * * \\
(0.000)\end{array}$ & $\begin{array}{l}1.162 * * * \\
(0.000)\end{array}$ & $\begin{array}{c}0.706 * * * \\
(0.000)\end{array}$ & $\begin{array}{c}0.801^{* * *} \\
(0.000)\end{array}$ & $\begin{array}{c}0.889 * * * \\
(0.000)\end{array}$ \\
\hline GDP Growth & $\begin{array}{c}0.077 * * * \\
(0.000)\end{array}$ & $\begin{array}{c}0.080 * * * \\
(0.000)\end{array}$ & $\begin{array}{c}0.064^{* * *} \\
(0.000)\end{array}$ & $\begin{array}{c}0.018 * * \\
(0.029)\end{array}$ & $\begin{array}{c}0.023 * * \\
(0.011)\end{array}$ & $\begin{array}{c}0.019 * * \\
(0.038)\end{array}$ \\
\hline Trade/GDP & $\begin{array}{c}0.015^{* * * *} \\
(0.000)\end{array}$ & $\begin{array}{c}0.014 * * * \\
(0.000)\end{array}$ & $\begin{array}{c}0.017 * * * \\
(0.000)\end{array}$ & $\begin{array}{c}0.011^{* * *} \\
(0.000)\end{array}$ & $\begin{array}{c}0.011 * * * \\
(0.000)\end{array}$ & $\begin{array}{c}0.008 * * * \\
(0.000)\end{array}$ \\
\hline Constant & $\begin{array}{l}0.922 * * * \\
(0.000)\end{array}$ & $\begin{array}{c}0.015 * * * \\
(0.000)\end{array}$ & $\begin{array}{l}0.019 * * * \\
(0.000)\end{array}$ & $\begin{array}{l}3.244 * * * \\
(0.000)\end{array}$ & $\begin{array}{c}2.872^{* * *} \\
(0.000)\end{array}$ & $\begin{array}{l}2.579 * * * \\
(0.000)\end{array}$ \\
\hline Sargan Test (p-value) & 0.5171 & 0.5478 & 0.8208 & 0.7425 & 0.7563 & 0.6421 \\
\hline $\begin{array}{l}2^{\text {nd }} \text { Order aucorrelation } \\
\text { (P-value) }\end{array}$ & 0.7879 & 0.7459 & 0.7859 & 0.1680 & 0.2051 & 0.1720 \\
\hline $\begin{array}{l}\text { Number of } \\
\text { Observations }\end{array}$ & 154 & 154 & 157 & 125 & 125 & 128 \\
\hline Number of Countries & 35 & 35 & 35 & 28 & 28 & 28 \\
\hline
\end{tabular}

Notes: * denotes significant at $10 \%$; **significant at $5 \%$ and $* * *$ significant at $1 \%$. P values are in parentheses. Aggregate aid is the sum of bilateral and multilateral aid. 
Table 5

Effect of Aid and Risk on FDI: System GMM Estimations

\begin{tabular}{|l|c|c|c|c|c|c|}
\hline \multirow{3}{*}{ Variables } & \multicolumn{3}{|c|}{ Low-Income Countries } & \multicolumn{3}{c|}{ Sub-Saharan Africa } \\
\cline { 2 - 7 } & Aggregate & Bilateral & Multilateral & Aggregate & Bilateral & Multilateral \\
& Aid & Aid & Aid & Aid & Aid & Aid \\
\hline Risk $(\hat{\alpha})$ & $-0.341^{* * *}$ & $-0.305^{* * *}$ & $-0.311^{* * *}$ & $-0.489^{* * *}$ & $-0.474^{* * *}$ & $-0.436^{* * *}$ \\
& $(0.000)$ & $(0.000)$ & $(0.000)$ & $(0.000)$ & $(0.000)$ & $(0.000)$ \\
\hline \multirow{2}{*}{ Risk*Aid $(\hat{\beta})$} & $0.006^{* * *}$ & $0.006^{* *}$ & $0.013^{* * *}$ & $0.014^{* * *}$ & $0.022^{* * *}$ & $0.027^{* * *}$ \\
& $(0.000)$ & $(0.019)$ & $(0.000)$ & $(0.000)$ & $(0.000)$ & $(0.000)$ \\
\hline
\end{tabular}

Notes: * denotes significant at $10 \%$; **significant at $5 \%$ and $* * *$ significant at $1 \%$. P values are in parentheses. Aggregate aid is the sum of bilateral and multilateral aid.

Table 6

Values of Aid at $25^{\text {th }}, 50^{\text {th }}$ and $75^{\text {th }}$ Percentile for Sample Groups

\begin{tabular}{|l|c|c|c|c|c|c|}
\hline \multirow{3}{*}{ Variables } & \multicolumn{3}{|c|}{ Low-Income Countries } & \multicolumn{3}{c|}{ Sub-Saharan Africa } \\
\cline { 2 - 7 } & $\begin{array}{c}25^{\text {th }} \\
\text { Percentile }\end{array}$ & $\begin{array}{c}50^{\text {th }} \\
\text { Percentile }\end{array}$ & $\begin{array}{c}75^{\text {th }} \\
\text { Percentile }\end{array}$ & $\begin{array}{c}25^{\text {th }} \\
\text { Percentile }\end{array}$ & $\begin{array}{c}50^{\text {th }} \\
\text { Percentile }\end{array}$ & $\begin{array}{c}75^{\text {th }} \\
\text { Percentile }\end{array}$ \\
\hline Aggregate Aid & 4.293 & 9.874 & 16.052 & 4.019 & 10.109 & 15.260 \\
\hline Bilateral Aid & 2.801 & 5.803 & 10.076 & 2.797 & 5.697 & 9.737 \\
\hline Multilateral Aid & 1.355 & 3.299 & 6.041 & 1.213 & 3.787 & 6.248 \\
\hline
\end{tabular}

Notes: * denotes significant at $10 \%$; **significant at $5 \%$ and $* * *$ significant at $1 \%$. P values are in parentheses. Aggregate aid is the sum of bilateral and multilateral aid. 
Table 7

Effect of a one-unit change in RISK on FDI (i.e., ${ }^{\partial F D I} / \partial R I S K=\hat{\alpha}+\hat{\beta} *$ Aid ) evaluated at the $25^{\text {th }}, 50^{\text {th }}$ and $75^{\text {th }}$ Percentile of Aid.

\begin{tabular}{|c|c|c|c|c|c|c|}
\hline \multicolumn{7}{|c|}{ Panel A: Difference GMM Estimations } \\
\hline \multirow[t]{2}{*}{ Type of Aid } & \multicolumn{3}{|c|}{ Low-Income Countries } & \multicolumn{3}{|c|}{ Sub-Saharan Africa } \\
\hline & $\begin{array}{c}25^{\text {th }} \\
\text { Percentile } \\
\end{array}$ & $\begin{array}{c}50^{\text {th }} \\
\text { Percentile }\end{array}$ & $\begin{array}{c}75^{\text {th }} \\
\text { Percentile }\end{array}$ & $\begin{array}{c}25^{\text {th }} \\
\text { Percentile }\end{array}$ & $\begin{array}{c}50^{\text {th }} \\
\text { Percentile }\end{array}$ & $\begin{array}{c}75^{\text {th }} \\
\text { Percentile }\end{array}$ \\
\hline Aggregate Aid & $\begin{array}{c}-0.279 * * * \\
(0.000)\end{array}$ & $\begin{array}{c}-0.223^{* * *} \\
(0.000)\end{array}$ & $\begin{array}{c}-0.162 * * * \\
(0.000) \\
\end{array}$ & $\begin{array}{c}-0.463^{* * *} \\
(0.000)\end{array}$ & $\begin{array}{c}-0.346^{* * *} \\
(0.000)\end{array}$ & $\begin{array}{c}-0.246 * * * \\
(0.000) \\
\end{array}$ \\
\hline Bilateral Aid & $\begin{array}{c}-0.287 * * * \\
(0.000)\end{array}$ & $\begin{array}{c}-0.244 * * * \\
(0.000)\end{array}$ & $\begin{array}{c}-0.180^{* * * *} \\
(0.000)\end{array}$ & $\begin{array}{c}-0.433^{* * *} \\
(0.000)\end{array}$ & $\begin{array}{c}-0.345^{* * * *} \\
(0.000)\end{array}$ & $\begin{array}{c}-0.223^{* * *} \\
(0.000)\end{array}$ \\
\hline Multilateral Aid & $\begin{array}{c}-0.199 * * * \\
(0.000) \\
\end{array}$ & $\begin{array}{c}-0.163 * * * \\
(0.000) \\
\end{array}$ & $\begin{array}{c}-0.111^{* * *} \\
(0.000)\end{array}$ & $\begin{array}{c}-0.410 * * * \\
(0.000)\end{array}$ & $\begin{array}{c}-0.321^{* * *} \\
(0.000)\end{array}$ & $\begin{array}{c}-0.236 * * * \\
(0.000) \\
\end{array}$ \\
\hline \multicolumn{7}{|c|}{ Panel B: System GMM Estimations } \\
\hline \multirow[t]{2}{*}{ Type of Aid } & \multicolumn{3}{|c|}{ Low-Income Countries } & \multicolumn{3}{|c|}{ Sub-Saharan Africa } \\
\hline & $\begin{array}{c}25^{\text {th }} \\
\text { Percentile }\end{array}$ & $\begin{array}{c}50^{\text {th }} \\
\text { Percentile }\end{array}$ & $\begin{array}{c}75^{\text {th }} \\
\text { Percentile }\end{array}$ & $\begin{array}{c}25^{\text {th }} \\
\text { Percentile }\end{array}$ & $\begin{array}{c}50^{\text {th }} \\
\text { Percentile }\end{array}$ & $\begin{array}{c}75^{\text {th }} \\
\text { Percentile }\end{array}$ \\
\hline Aggregate Aid & $\begin{array}{c}-0.317 * * * \\
(0.000)\end{array}$ & $\begin{array}{c}-0.285^{* * *} \\
(0.000)\end{array}$ & $\begin{array}{c}-0.250 * * * \\
(0.000)\end{array}$ & $\begin{array}{c}-0.432 * * * \\
(0.000)\end{array}$ & $\begin{array}{c}-0.347 * * * \\
(0.000)\end{array}$ & $\begin{array}{c}-0.274 * * * \\
(0.000)\end{array}$ \\
\hline Bilateral Aid & $\begin{array}{c}-0.288^{* * *} \\
(0.000)\end{array}$ & $\begin{array}{c}-0.270^{* * *} \\
(0.000)\end{array}$ & $\begin{array}{c}-0.173^{* * *} \\
(0.000)\end{array}$ & $\begin{array}{c}-0.413^{* * *} \\
(0.000)\end{array}$ & $\begin{array}{c}-0.349 * * * \\
(0.000)\end{array}$ & $\begin{array}{c}-0.262 * * * \\
(0.000) \\
\end{array}$ \\
\hline Multilateral Aid & $\begin{array}{c}-0.293 * * * \\
(0.000)\end{array}$ & $\begin{array}{c}-0.267 * * * \\
(0.000)\end{array}$ & $\begin{array}{c}-0.230 * * * \\
(0.000)\end{array}$ & $\begin{array}{c}-0.402 * * * \\
(0.000)\end{array}$ & $\begin{array}{c}-0.332 * * * \\
(0.000)\end{array}$ & $\begin{array}{c}-0.264 * * * \\
(0.000)\end{array}$ \\
\hline
\end{tabular}

Notes: * denotes significant at $10 \%$; $* *$ significant at $5 \%$ and $* * *$ significant at $1 \%$. P values are in parentheses. Aggregate aid is the sum of bilateral and multilateral aid.

\section{Table 8}

The Critical Values of Aid, Aid $^{*}$ and the (actual) values of Aid averaged from 1983-2004, $\overline{\text { Aid }}$.

\begin{tabular}{|l|c|c|c|c|c|c|}
\hline \multirow{2}{*}{ Type of Aid } & \multicolumn{3}{|c|}{ Low-Income Countries } & \multicolumn{3}{c|}{ Sub-Saharan Africa } \\
\cline { 2 - 7 } & $\begin{array}{c}\text { Average } \\
\text { Aid, Aid }\end{array}$ & $\begin{array}{c}\text { Aid }^{*}, \\
\text { Difference- } \\
\text { GMM }\end{array}$ & $\begin{array}{c}\text { Aid }^{*}, \\
\text { System- } \\
\text { GMM }\end{array}$ & $\begin{array}{c}\text { Average Aid, } \\
\overline{\text { Aid }}\end{array}$ & $\begin{array}{c}\text { Aid }^{*}, \\
\text { Difference- } \\
\text { GMM }\end{array}$ & $\begin{array}{c}\text { Aid }^{*}, \\
\text { System- } \\
\text { GMM }\end{array}$ \\
\hline Aggregate Aid & 12.340 & 32.2 & 56.833 & 12.602 & 28.421 & 34.929 \\
\hline Bilateral Aid & 7.759 & 22.0 & 50.833 & 7.773 & 17.267 & 21.546 \\
\hline Multilateral Aid & 4.581 & 11.842 & 23.923 & 4.829 & 13.294 & 16.148 \\
\hline
\end{tabular}

Notes: The critical value of aid, Aid $^{*}$, is the amount of aid that completely neutralizes the adverse risk of FDI. Thus, it the value of aid at which ${ }^{\partial F D I} / \partial R I S K=0$. 


\section{Table 9}

\section{Joint Estimation of FDI and Aid: Three-Stage Least Squares Estimation}

\begin{tabular}{|c|c|c|c|c|c|c|}
\hline \multicolumn{7}{|c|}{ Panel A: Estimates for FDI Equation } \\
\hline \multirow[t]{2}{*}{ Variables } & \multicolumn{3}{|c|}{ Low-Income } & \multicolumn{3}{|c|}{ Sub-Saharan Africa } \\
\hline & Aggregate & Bilateral & Multilateral & Aggregate & Bilateral & Multilateral \\
\hline Risk & $\begin{array}{c}-0.285^{* * *} \\
(0.001)\end{array}$ & $\begin{array}{c}-0.254^{* * *} \\
(0.005)\end{array}$ & $\begin{array}{c}-0.232 * * * \\
(0.005)\end{array}$ & $\begin{array}{c}-0.264^{* * *} \\
(0.008)\end{array}$ & $\begin{array}{c}-0.219 * * \\
(0.037)\end{array}$ & $\begin{array}{c}-0.212 * * \\
(0.024)\end{array}$ \\
\hline Aid & $\begin{array}{c}-0.112 * * * \\
(0.001)\end{array}$ & $\begin{array}{c}-0.165 * * * \\
(0.006)\end{array}$ & $\begin{array}{c}-0.183^{* *} \\
(0.011)\end{array}$ & $\begin{array}{c}-0.108 * * * \\
(0.001)\end{array}$ & $\begin{array}{c}-0.169 * * * \\
(0.003)\end{array}$ & $\begin{array}{c}-0.172 * * * \\
(0.001)\end{array}$ \\
\hline Risk*lagged Aid & $\begin{array}{c}0.015^{* * * *} \\
(0.000)\end{array}$ & $\begin{array}{c}0.021^{* * * *} \\
(0.000)\end{array}$ & $\begin{array}{c}0.026^{* * * *} \\
(0.001)\end{array}$ & $\begin{array}{c}0.013^{* * * *} \\
(0.000)\end{array}$ & $\begin{array}{c}0.019 * * * \\
(0.002)\end{array}$ & $\begin{array}{c}0.022^{* * * *} \\
(0.003)\end{array}$ \\
\hline \multicolumn{7}{|l|}{ Control Variables } \\
\hline Lagged FDI/GDP & $\begin{array}{l}0.170^{*} \\
(0.054)\end{array}$ & $\begin{array}{c}0.187 * * \\
(0.044)\end{array}$ & $\begin{array}{c}0.231^{* * *} \\
(0.008)\end{array}$ & $\begin{array}{c}0.286 * * \\
(0.014)\end{array}$ & $\begin{array}{c}0.314 * * \\
(0.011)\end{array}$ & $\begin{array}{c}0.367 * * * \\
(0.001)\end{array}$ \\
\hline $\ln (1+$ Phones $)$ & $\begin{array}{c}0.131 \\
(0.554)\end{array}$ & $\begin{array}{l}0.0870 \\
(0.707) \\
\end{array}$ & $\begin{array}{c}0.301 \\
(0.166) \\
\end{array}$ & $\begin{array}{c}-0.0371 \\
(0.899)\end{array}$ & $\begin{array}{l}0.0236 \\
(0.939)\end{array}$ & $\begin{array}{c}0.114 \\
(0.688)\end{array}$ \\
\hline GDP Growth & $\begin{array}{c}0.108 * * * \\
(0.009)\end{array}$ & $\begin{array}{c}0.124^{* * * *} \\
(0.004)\end{array}$ & $\begin{array}{c}0.0844 * * \\
(0.041)\end{array}$ & $\begin{array}{l}0.110 * * \\
(0.0145)\end{array}$ & $\begin{array}{c}0.126^{* * * *} \\
(0.008)\end{array}$ & $\begin{array}{c}0.091 * * \\
(0.040)\end{array}$ \\
\hline Trade/GDP & $\begin{array}{c}0.0205 * * * \\
(0.000)\end{array}$ & $\begin{array}{c}0.0206 * * * \\
(0.001)\end{array}$ & $\begin{array}{c}0.0178 * * * \\
(0.002)\end{array}$ & $\begin{array}{c}0.0168 * * \\
(0.017)\end{array}$ & $\begin{array}{c}0.0166 * * \\
(0.026)\end{array}$ & $\begin{array}{c}0.0164^{* *} \\
(0.017) \\
\end{array}$ \\
\hline Constant & $\begin{array}{l}1.497 * \\
(0.096\end{array}$ & $\begin{array}{c}1.308 \\
(0.161)\end{array}$ & $\begin{array}{c}0.948 \\
(0.262)\end{array}$ & $\begin{array}{c}1.915 * \\
(0.0747)\end{array}$ & $\begin{array}{c}1.510 \\
(0.183)\end{array}$ & $\begin{array}{c}1.229 \\
(0.219)\end{array}$ \\
\hline Observations & 134 & 134 & 139 & 99 & 99 & 102 \\
\hline No of Countries & 33 & 33 & 33 & 23 & 23 & 23 \\
\hline R-squared & 0.337 & 0.318 & 0.348 & 0.325 & 0.289 & 0.357 \\
\hline \multicolumn{7}{|c|}{ Panel B: Estimates for Aid Equation } \\
\hline \multirow[t]{2}{*}{ Variables } & \multicolumn{3}{|c|}{ Low-Income } & \multicolumn{3}{|c|}{ Sub-Saharan Africa } \\
\hline & Aggregate & Bilateral & Multilateral & Aggregate & Bilateral & Multilateral \\
\hline FDI/GDP & $\begin{array}{l}2.844^{* * *} \\
(0.000)\end{array}$ & $\begin{array}{l}1.803^{* * *} \\
(0.000)\end{array}$ & $\begin{array}{l}1.017^{* * * *} \\
(0.000)\end{array}$ & $\begin{array}{l}3.641 * * * \\
(0.000)\end{array}$ & $\begin{array}{l}2.143^{* * * *} \\
(0.000)\end{array}$ & $\begin{array}{l}1.426^{* * * *} \\
(0.000)\end{array}$ \\
\hline Control Variables & & & & & & \\
\hline Debt Service/Exports & $\begin{array}{c}0.405^{* * * *} \\
(0.000) \\
\end{array}$ & $\begin{array}{c}0.230^{* * * *} \\
(0.000) \\
\end{array}$ & $\begin{array}{c}0.171^{* * * *} \\
(0.000)\end{array}$ & $\begin{array}{c}0.397 * * * \\
(0.000) \\
\end{array}$ & $\begin{array}{c}0.219 * * * \\
(0.002) \\
\end{array}$ & $\begin{array}{c}0.167 * * * \\
(0.000) \\
\end{array}$ \\
\hline Inflation & $\begin{array}{l}0.166 * \\
(0.064)\end{array}$ & $\begin{array}{l}0.0508 \\
(0.414) \\
\end{array}$ & $\begin{array}{c}0.0884^{* * *} \\
(0.001\end{array}$ & $\begin{array}{c}0.166 \\
(0.126) \\
\end{array}$ & $\begin{array}{l}0.0376 \\
(0.629) \\
\end{array}$ & $\begin{array}{c}0.115^{* * * *} \\
(0.000) \\
\end{array}$ \\
\hline Inflation*Inflation & $\begin{array}{c}-0.00107 \\
(0.396) \\
\end{array}$ & $\begin{array}{c}-0.0000879 \\
(0.920)\end{array}$ & $\begin{array}{c}-0.000581^{* *} \\
(0.027)\end{array}$ & $\begin{array}{c}-0.000724 \\
(0.640)\end{array}$ & $\begin{array}{c}0.000273 \\
(0.806)\end{array}$ & $\begin{array}{c}-0.001^{* * *} \\
(0.003)\end{array}$ \\
\hline Log (Population) & $\begin{array}{c}-4.194 * * * \\
(0.000)\end{array}$ & $\begin{array}{c}-2.569 * * * \\
(0.000)\end{array}$ & $\begin{array}{c}-1.621 * * * \\
(0.000)\end{array}$ & $\begin{array}{c}-6.601 * * * \\
(0.000)\end{array}$ & $\begin{array}{c}-3.863 * * * \\
(0.000)\end{array}$ & $\begin{array}{c}-2.749 * * * \\
(0.000)\end{array}$ \\
\hline Constant & $\begin{array}{c}99.83^{* * * *} \\
(0.000)\end{array}$ & $\begin{array}{c}57.45^{* * * *} \\
(0.000)\end{array}$ & $\begin{array}{c}42.22 * * * \\
(0.000)\end{array}$ & $\begin{array}{c}128.6^{* * * *} \\
(0.000)\end{array}$ & $\begin{array}{c}3.59 * * * \\
(0.000)\end{array}$ & $\begin{array}{c}55.07 * * * \\
(0.000)\end{array}$ \\
\hline Observations & 134 & 134 & 139 & 99 & 99 & 102 \\
\hline No of Countries & 33 & 33 & 33 & 23 & 23 & 23 \\
\hline R-squared & 0.537 & 0.447 & 0.587 & 0.565 & 0.438 & 0.661 \\
\hline
\end{tabular}

Notes: * denotes significant at $10 \%$; **significant at $5 \%$ and $* * *$ significant at $1 \%$. P values are in parentheses. Aggregate aid is the sum of bilateral and multilateral aid. 
Table 10

Values of Aid at $10^{\text {th }}, 25^{\text {th }}, 50^{\text {th }}$ and $75^{\text {th }}$ Percentile

\begin{tabular}{|l|c|c|c|c|c|c|c|c|}
\hline & \multicolumn{4}{|c|}{ Low-Income Countries } & \multicolumn{4}{c|}{ Sub-Saharan Africa } \\
\hline & $\begin{array}{c}10^{\text {th }} \\
\text { Percentile }\end{array}$ & $\begin{array}{c}25^{\text {th }} \\
\text { Percentile }\end{array}$ & $\begin{array}{c}50^{\text {th }} \\
\text { Percentile }\end{array}$ & $\begin{array}{c}75^{\text {th }} \\
\text { Percentile }\end{array}$ & $\begin{array}{c}10^{\text {th }} \\
\text { Percentile }\end{array}$ & $\begin{array}{c}25^{\text {th }} \\
\text { Percentile }\end{array}$ & $\begin{array}{c}50^{\text {th }} \\
\text { Percentile }\end{array}$ & $\begin{array}{c}75^{\text {th }} \\
\text { Percentile }\end{array}$ \\
\hline $\begin{array}{l}\text { Aggregate } \\
\text { Aid }\end{array}$ & 2.209 & 4.791 & 11.070 & 16.675 & 3.066 & 5.933 & 12.053 & 16.883 \\
\hline Bilateral Aid & 1.260 & 3.135 & 6.463 & 10.250 & 1.786 & 3.882 & 7.121 & 10.250 \\
\hline $\begin{array}{l}\text { Multilateral } \\
\text { Aid }\end{array}$ & 0.494 & 1.465 & 3.616 & 6.022 & 3.066 & 0.501 & 4.586 & 6.550 \\
\hline
\end{tabular}

Notes: The values of aid are different from that of Table 5 because the sample sizes are different. Data for some of the variables included in the Aid equation was not available for a few countries.

Table 11

Effect of a one-unit change in RISK on FDI (i.e., ${ }^{2 F D I} / \partial R I S K=\hat{\alpha}+\hat{\beta}^{*}$ Aid ) evaluated at the $10^{\text {th }}, 25^{\text {th }}, 50^{\text {th }}$ and $75^{\text {th }}$ Percentile of Aid.

\begin{tabular}{|l|c|c|c|c|c|c|c|c|}
\hline \multirow{2}{*}{ Type of Aid } & \multicolumn{3}{|c|}{ Low-Income Countries } & \multicolumn{4}{|c|}{ Sub-Saharan Africa } \\
\cline { 2 - 8 } & $\begin{array}{c}10^{\text {th }} \\
\text { percentile }\end{array}$ & $25^{\text {th }}$ Percentile & $\begin{array}{c}50^{\text {th }} \\
\text { Percentile }\end{array}$ & $\begin{array}{c}75^{\text {th }} \\
\text { Percentile }\end{array}$ & $\begin{array}{c}10 \text { th } \\
\text { percentile }\end{array}$ & $\begin{array}{c}25^{\text {th }} \\
\text { Percentile }\end{array}$ & $\begin{array}{c}50^{\text {th }} \\
\text { Percentile }\end{array}$ & $\begin{array}{c}75^{\text {th }} \\
\text { Percentile }\end{array}$ \\
\hline Aggregate & $-0.250^{* * *}$ & $-0.210^{* * *}$ & -0.112 & -0.0245 & $-0.224^{* *}$ & $-0.185^{* *}$ & -0.104 & -0.039 \\
Aid & $(0.003)$ & $(0.008)$ & $(0.139)$ & $(0.755)$ & $(0.019)$ & $(0.044)$ & $(0.249)$ & $(0.670)$ \\
\hline Bilateral & $-0.227^{* * *}$ & $-0.186^{* *}$ & -0.113 & -0.030 & $-0.185^{*}$ & -0.145 & -0.083 & -0.024 \\
Aid & $(0.009)$ & $(0.025)$ & $(0.157)$ & $(0.716)$ & $(0.67)$ & $(0.137)$ & $(0.384)$ & $(0.808)$ \\
\hline Multilateral & $-.219^{* * *}$ & $-0.193^{* *}$ & $-0.135^{*}$ & -0.070 & $-0.201^{* * *}$ & $-0.168^{*}$ & -0.111 & -0.068 \\
Aid & $(0.001)$ & $(0.013)$ & $(0.073)$ & $(0.361)$ & $(0.003)$ & $(0.061)$ & $(0.209)$ & $(0.451)$ \\
\hline
\end{tabular}

Notes: $*$ denotes significant at $10 \%$; $* *$ significant at $5 \%$ and $* * *$ significant at $1 \%$. P values are in parentheses. Aggregate aid is the sum of bilateral and multilateral aid.

Table 12

The Critical Values of Aid, Aid $^{*}$ and the (actual) values of Aid averaged from 1983-2004, $\overline{\text { Aid }}$.

\begin{tabular}{|l|c|c|c|c|c|c|}
\hline & \multicolumn{3}{|c|}{ Low-Income Countries } & \multicolumn{2}{|c|}{ Sub-Saharan Africa } \\
\hline Aid, $\frac{\text { Aid }}{\text { Average }}$ & $\begin{array}{c}\text { Critical values of } \\
\text { Aid, Aid }\end{array}$ & $\begin{array}{c}\text { Number and } \\
\text { Percentage of } \\
\text { countries for } \\
\text { which } \\
\text { Aid }>\text { Aid }^{*}\end{array}$ & $\begin{array}{c}\text { Average Aid, } \\
\overline{\text { Aid }}\end{array}$ & Aid $^{*}$ & $\begin{array}{c}\text { Number and } \\
\text { Percentage of } \\
\text { countries for } \\
\text { which } \\
\frac{\text { Aid }^{*}}{\text { Aid }^{*}}\end{array}$ \\
\hline Aggregate Aid & 12.523 & 18.269 & $7(21 \%)$ & 14.041 & 19.850 & $5(21 \%)$ \\
\hline Bilateral Aid & 7.727 & 11.598 & $7(21 \%)$ & 8.503 & 11.526 & $5(21 \%)$ \\
\hline $\begin{array}{l}\text { Multilateral } \\
\text { Aid }\end{array}$ & 4.795 & 8.657 & $5(15 \%)$ & 5.538 & 9.636 & $5(21 \%)$ \\
\hline
\end{tabular}

Notes: The critical value of aid, Aid $^{*}$, is the amount of aid that completely neutralizes the adverse risk

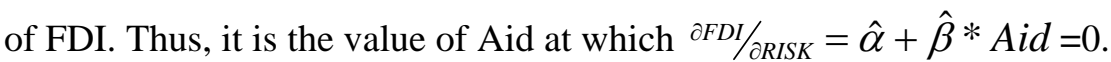

